TIPA. Travaux interdisciplinaires sur la parole et le langage

$36 \mid 2020$

Comment le corps coconstruit les discours et le sens

\title{
Analyzing interactive dimension of teacher gestures in naturalistic instructional contexts
}

Une analyse de la dimension interactive des gestes pédagogiques en contexte naturel

Can Denizci et Brahim Azaoui

\section{OpenEdition}

\section{Journals}

Édition électronique

URL : http://journals.openedition.org/tipa/3843

DOI : 10.4000/tipa.3843

ISSN : 2264-7082

Éditeur

Laboratoire Parole et Langage

Référence électronique

Can Denizci et Brahim Azaoui, « Analyzing interactive dimension of teacher gestures in naturalistic instructional contexts », TIPA. Travaux interdisciplinaires sur la parole et le langage [En ligne], 36 | 2020, mis en ligne le 01 juin 2020, consulté le 27 janvier 2021. URL : http://journals.openedition.org/tipa/ 3843 ; DOI : https://doi.org/10.4000/tipa.3843

Ce document a été généré automatiquement le 27 janvier 2021.

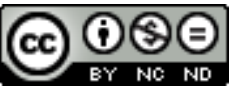

La revue TIPA. Travaux interdisciplinaires sur la parole et le langage est mise à disposition selon les termes de la licence Creative Commons Attribution - Pas d'Utilisation Commerciale - Pas de Modification 4.0 International 


\title{
Analyzing interactive dimension of teacher gestures in naturalistic instructional contexts
}

Une analyse de la dimension interactive des gestes pédagogiques en contexte naturel

\author{
Can Denizci et Brahim Azaoui
}

\section{Introduction}

1 Since Goffman's (1956) work, it has been accepted that social encounters are intrinsically multimodal, i.e. implying beside the verbal production various non-verbal parameters such as gestures, proxemics, posture, facial expression, etc. The research concerned more specifically with gestures has shown the importance of this visible action (Kendon, 2004), and various works have been proposed to understand its relation to speech and thought (Kita \& Ozyurek, 2003; McNeill, 1992, 2005; De Ruiter, 2007 among others) and its role in the interaction (Goodwin, 2000; Streeck, 2009; Mondada, 2013). Reflections concerning the classification of these gestures have led to several propositions (Ekman \& Friesen, 1969; Efron, 1972; Cosnier, 1982; Kendon, 1988; McNeill, 1992) which basically boil down to three major dimensions: emotional, referential and discursive.

2 When Bavelas et al. $(1992,1995)$ proposed to take into account an interactive gesture category, their first argument was that previous gesture research was based on data deriving from monologal contexts. Yet, they observed, most common settings for discourse production were face-to-face dialogues, which introduces the need for interlocutors to coordinate their dialogue or to refer to the addressee. Although Bavelas et al.'s $(1992,1995)$ initial argument was coherent with a social approach to conversation, we believe that a broader definition of interaction may also be 
considered and that interactive gestures may encompass settings with more than two participants (Goffman, 1981).

3 Instructional contexts constitute one example. It can be admitted that classrooms, as socially organized sites (Tabenksy, 2014: 1427), are notably defined by their polylogal and polyfocal dimensions (Rivière \& Bouchard, 2011; Azaoui, 2014, 2015a). By polyfocal, we mean that the teacher often directs his attention to a multiplicity of foci of interest, and polylogal refers to the idea that more than three students may speak simultaneously. These dimensions make teachers' multimodal management of interaction more complex (Azaoui, 2015a). For example, psycholinguistic research on gestures has evidenced that the number of participants in an interaction and the participants' location bring changes in the speaker's gesture direction (Ozyurek, 2002). Complementary to this, in a conversational analysis of multi-party participatory debates, Mondada (2013) showed how turn-taking was organised at a multimodal level. In particular, the results show how two-handedness, as we define it (see $\S 4.2 .6$ ), contributes to the chairman's ability to select and queue multiple next speakers. In a similar way, because there is more than one addressee at a time in instructional contexts, teachers' gaze becomes a valuable source of information as to the identity of his/her interlocutor (Azaoui, 2015a).

In short, in the wake of Bourdieu (1984), we believe that concepts in general ought not to be fetichized; they need to be tested and under regular evaluation. Consequently, we believe that categories must be seen to be but temporary devices used locally (Kendon, 2004: 107). Therefore, the question we ask ourselves is how instructional contexts can help us revise and update our understanding of category of interactive gestures, often used in research in educational setting without being questioned as if it were automatically adapted to this context.

Our study, based upon video corpora of classroom interactions in secondary schools in France and Turkey, aims to examine the category of interactive gestures in this setting with its specificities. Among these we can mention at least two that need to be considered in the analyses: (i) its numerical reality, in the sense that more often than not, around 30 students are gathered in a constraint environment and that this parameter, needs to be considered in analyses (Cambra Giné, 2003), and (ii) the turntaking machinery (Gülich \& Mondada, 2001), which refers to the specificity of how speech is organized in instructional contexts. We will try to answer the following questions: To what extent are interactive gestures as defined by Bavelas et al. (1992, 1995) operable for describing gestures in language classroom? Can we observe a gradation in the interactivity dimension among the gestures under scrutiny? How can the initial definition of this gestural category be adapted to instructional contexts?

\section{Theoretical framework}

6 In the theoretical part of this study, the classifications and the functions of gestures in everyday communication and in classroom interactions will be mentioned first. Secondly, the issue of interactive gestures will be explored around three subparts: definition, criteria and subfunctions. Lastly, the specificities of classroom interactions will be examined in terms of their polyfocal and plurisemiotic character. 


\subsection{Gestures in interactions}

7 This section will present gestures' classification as considered by McNeill $(1992,2005)$ and gestures' functions both in everyday communication and in instructional contexts.

\subsubsection{Gesture classification}

8 Since Efron's (1972) major work $^{1}$, researchers have regularly proposed various classifications to categorize gestures; this paper draws on the proposition by McNeill (1992: 78) who distinguishes between gestures and non-gestures: the latter comprise selftouching and object-manipulation. As for gestures, McNeill organizes them into four $\operatorname{continua}^{2}$ (Table 1) (McNeill, 2005: 7). The table below shows the one regarding gestures' relationship to speech:

Table 1. Kendon's first continuum (McNeill, 2005)

\begin{tabular}{|l|l|l|l|}
\hline Gesticulation & Emblems & Pantomime & $\begin{array}{l}\text { Sign } \\
\text { language }\end{array}$ \\
\hline $\begin{array}{l}\text { Obligatory presence of } \\
\text { speech }\end{array}$ & $\begin{array}{l}\text { Optional presence of } \\
\text { speech }\end{array}$ & $\begin{array}{l}\text { Obligatory absence of } \\
\text { speech }\end{array}$ & The same \\
\hline
\end{tabular}

In the scope of this study, the dimensions we deal with are respectively gesticulation or spontaneous movements of the hands and arms accompanying speech (McNeill, 1992: 37), comprising gestures which are meaningful only in conjunction with the [corresponding] utterance, and emblems, as culturally conventional gestures, which can be made with speech or not (McNeill, 2005: 7). Furthermore, it should also be noted that the gestures analyzed within this study are pedagogical gestures in functional terms, i.e. gestures used by a language teacher for a pedagogical purpose $3^{3}$ (Tellier, 2008: $42^{4}$ ). In consequence, the gestures in question are based on co-verbal gesturing (McNeill et al., 2008: 118) performed with pedagogical aims.

As far as the communicative roles of gestures are concerned, according to Kendon (2004: 158-159), we may mention three fundamental functions: referential, pragmatic and interactive (or interpersonal). The referential function is fulfilled, when gestures [...] provide a representation of an aspect of the content of an utterance or when they contribute to the propositional content of an utterance by pointing to the object of reference in the discourse (Kendon, 2004: 160). In this perspective, these gestures may correspond to iconic, metaphoric gestures (and sometimes also to emblems) representing concrete/abstract concepts, and deictic ones pointing towards something in McNeill's (1992: 12-18) dimensional typology. From the functional perspective, the referential gestures correspond to topic gestures in Bavelas et al.'s (1992: 473) categorization.

11 As gestures may relate to features of an utterance's meaning that are not a part of its referential meaning or propositional content, they also play a pragmatic function (Kendon, 2004: 158). Within the pragmatic communicative function, three main subfunctions may be distinguished: when a gesture alters in some way the frame in terms of which what is being said in the utterance is to be interpreted, it plays a modal function (Kendon, 2004: 159). As we will discuss it later, an example to this gestural function may be seen in Figure 1. 


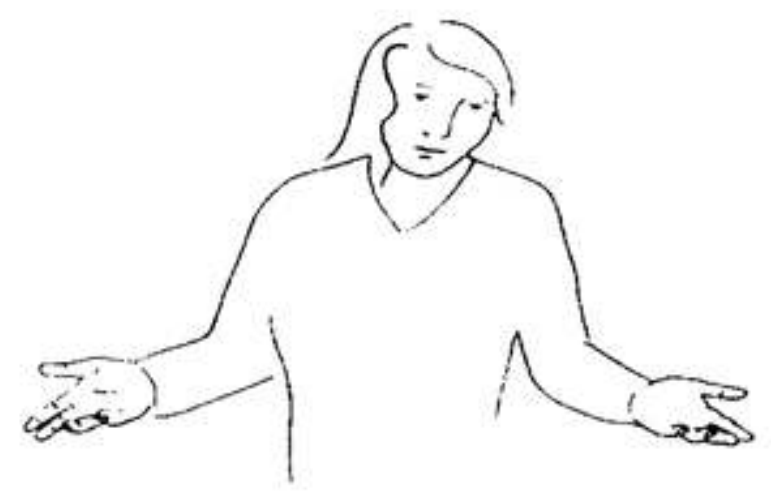

When a gesture is used to indicate the kind of speech act or interactional move a person is engaging in (Kendon, 2004: 159), it plays a performative function; we can give as examples to this function the gestures in Figure 2 and Figure 3.

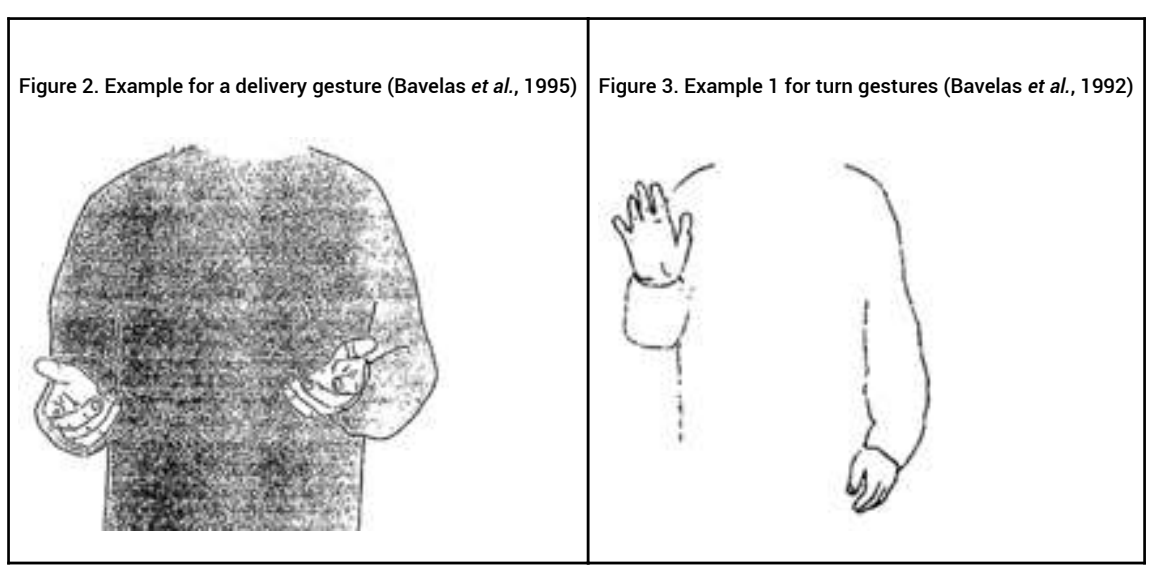

The third pragmatic subfunction is coined as parsing gestures by Kendon (2004: 159); here, the gesture operates as if it is punctuating the spoken discourse or marking out its different logical components. This definition brings to mind the gesture called beat which indexes the word or phrase it accompanies as being significant, not for its own semantic content, but for its discourse-pragmatic content (McNeill, 1992: 15). Hence, beats pragmatically draw attention to a word or a group of words by marking them at syntactic level; in general, they superimpose onto other gestural dimension (iconic, metaphoric, deictic or emblematic gestures) to function this way. All in all, the three subfunctions are considered as interactive in Bavelas et al.'s $(1992,1995)$ categorization, as we will discuss it later.

Kendon (2004: 159) designates gestures which regulate turns at talk as interactive or interpersonal gestures (see Figure 4). 
Figure 4. Example 2 for seeking gestures (Bavelas et al., 1992)

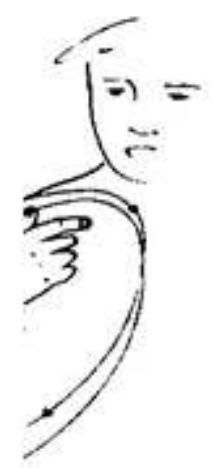

These gestures correspond solely to turn gestures in Bavelas et al.'s (1995: 397) categorization. Therefore, Kendon's definition of interactive gestures is somewhat restrictive. We think that, as all pragmatic gestures would function at both illocutionary and perlocutionary levels, they may be considered interactive as well. The relevance of interactive gestures arises from the fact that their pragmatic value or function prevails over their relationship to the semantic content of the utterance they accompany.

Therefore, interactivity does not uniquely involve turn gestures and comprises a wider range of pragmatic gestures because, as Streeck (2005, as cited in Payrató \& Teßendorf, 2014: 1533) points out, pragmatic gestures reveal aspects of the communicative interaction [...] displayed and they include:

recipient gestures (affirmation, negation, rejection, etc.), beats that mark speech units, pronominal referential gestures (mostly with pointing motions that mark acts of reference), pointing-like movements, gestures that express the stance/ attitude of the speaker, speech act [...] gestures that act upon the utterance.

For example, open hand supine gesture family (Kendon, 2004) and conduit metaphoric gestures (McNeill, 1992) may be considered pragmatic but also interactive (see Figures 1, 2 and 4 above and Footnote 8). In their various articles, Müller and her colleagues also coined the term recurrent gesture (as cited in Payrató \& Teßendorf, 2014: 1533) which refers to a functional gestural category which is used repeatedly in different contexts where its formational and semantic core remains stable across different contexts and speakers (for example, the palm up open hand gesture, see Footnote 8); thus, the pragmatic or recurrent gestures are interactive as well, for they provide interpretational frame for the interlocutor and take up an interactive role in consequence.

Lastly, as a recurrent gesture's formational and semantic core remains stable across different contexts, we contend that emblems which are partly conventionalized (McNeill, 2005: 10) and used repeatedly in specific instructional contexts may play interactive roles as well; this is especially the case for some teaching emblems (see Azaoui, 2013) that we will discuss later (see Figure 11 and Footnote 17).

\subsubsection{Gestures' functions in classroom interactions}

The functions of gestures are manifold, as they facilitate the comprehension of the message by the co-speaker (Alibali et al., 2009), they facilitate the production of speech (Goldin-Meadow et al., 2001) or help organize the turn-taking (Streeck \& Hartege, as cited in Gullberg, 2010). 

gestures: Didactic gestures are used for demonstrating meaning (such as the use of an iconic gesture for clarifying the meaning of a word for example), whereas the interactional ones promote dialogue in class. The first category corresponds to topic gestures, while the second one rather involves interactive gestures in Bavelas et al.'s (1992, 1995) categorization.

From an interactive point of view about teachers' gestures, Allen (1999: 474) highlights the following subfunctions: vary the tempo, control participation, signal changes, indicate who is to respond, cue choral response, mark beginnings and ends of lessons; in other words, teachers' gestures serve to ask a student to listen, repeat, answer, or speak louder, signal errors, promote dialogue and therefore stimulate classroom interaction (Allen, 2000: 171). For example, when a teacher claps her hands, the gesture may signal a new phase in the course, draw attention to a point of the didactic content or signal an error for interactive purposes.

more systematic approach, Tellier (2006: 109) distinguished three functional categories in terms of teachers' gestures within instructional contexts: information gestures, classroom management gestures and assessment gestures. The assessment function is undertaken by gestures aiming to assess students' interventions ${ }^{6}$ (felicitate/approve $a$ student, signal error), whereas the class management function is fulfilled with those used to organize class activities (for signalling a change in classroom activities, starting/closing an activity, giving instructions, etc.) and interactions ${ }^{7}$ (for regulating students' speech, taking/ giving turn, asking a question, etc.), and the information function comprises gestures conveying morpho-syntactic, phonologic/phonetic and lexical information ${ }^{8}$ that is apt to help students better understand their teachers' speech (Tellier, 2008: 42-44). We subscribe to Tellier's $(2006,2008)$ functional categorization in this study.

All in all, as Tabenksy (2014: 1426) points it out, teachers use effectively a variety of gestures to elucidate meaning, to assist in class participation and management, and to provide feedback. Furthermore, we should note that the above-mentioned gestural functions can be fulfilled through different gestural dimensions and that interactive gestures correspond mainly to classroom management gestures in the functional perspective, as shown in our corpora.

\subsection{Interactive gestures: an overview}

$$
\text { 1995) will be presented. }
$$

\subsubsection{Definition}

Bavelas et al. (1992) propose a functional gesture categorization by building it on Ekman and Friesen (1969: 470) who distinguish between stereotypic hand signals used in the absence of speech, called emblems (e.g. the thumb-up gesture meaning OK) and illustrators which are improvised during conversation. Bavelas et al. (1992: 472-473) divide illustrators into two subclasses: topic and interactive gestures.

Topic gestures depict semantic information directly related to the topic of discourse (Bavelas et al., 1992: 473). Interactive gestures, which we are concerned with, are gestures whose function is to aid the maintenance of conversation as a social system (Bavelas et al., 1992: 470).

TIPA. Travaux interdisciplinaires sur la parole et le langage, 36 | 2020 
In their later article, Bavelas et al. (1995: 394) justify such a gestural class by the fact that most of the previous research on gestures is based on data deriving from monologal contexts while there should be, according to them, a new functional category (called interactive gestures) helping the interlocutors coordinate their dialogue [...] [these interactive gestures] address and maintain the interaction required by dialogue rather than conveying meaning within the dialogue as other gestures do.

\subsubsection{Criteria for being an interactive gesture}

Bavelas et al. (1992: 473) determine two criteria for interactive gestures:

(1) semantic criteria: [T]hey refer directly to the interlocutor; they give no information about the topic. So, an interactive gesture must have a paraphrase that is both independent of the topic and addressed to the interlocutor.

(2) morphological criteria: [T] heir physical form which always includes some kind of iconic reference to the interlocutor (e.g. pointing at the other person with finger(s), thumb, or palm; but in most of the cases the morphology of the gesture can be more complex). So, limbs must be oriented directly toward the other person at some point, however briefly. For example, the back of the palm, heel of the hand, or closed hand are negative criteria.

\subsubsection{Subfunctions and examples of interactive gestures} ( et al., 1995: 395). A typical example for a delivery gesture is what Bavelas et al. (1992: 472) identify as a conduit metaphoric gesture (see Figure 1 below), and which is defined by McNeill (1992: 39) as a gesture where the speaker appears to be holding an object in the form of a cup or container. As far as the morphology of the gesture is concerned, the hand(s) is/are rotated outward slightly down from the speaker to the addressee with palm(s) facing up and fingers curled or spread to a certain degree (fingers may be more or less extended and adducted in some of its variants ${ }^{9}$ ). The gesturer seems to present, offer, or display something to the addressee, or show readiness to receive something (Kendon, 2004: 264). According to Parrill (2008: 204), although the gesture depicts a discourse theme as an object (thus exemplifying the IDEAS ARE OBJECTS metaphor), the main communicative objective is not the illustration of an abstract idea on the addressee's side but the maintenance of discourse. Thus, the gesture operates more on a pragmatic/discursive level.

31 Citing gestures serve to cite the addressee or to acknowledge an earlier contribution the addressee made, where equivalent paraphrases such as as you said earlier (see Figure 5), I see that you understood me, etc. may be implied (Bavelas et al., 1995: 396-397). 
Figure 5. Example for a citing gesture (Bavelas et al., 1995)

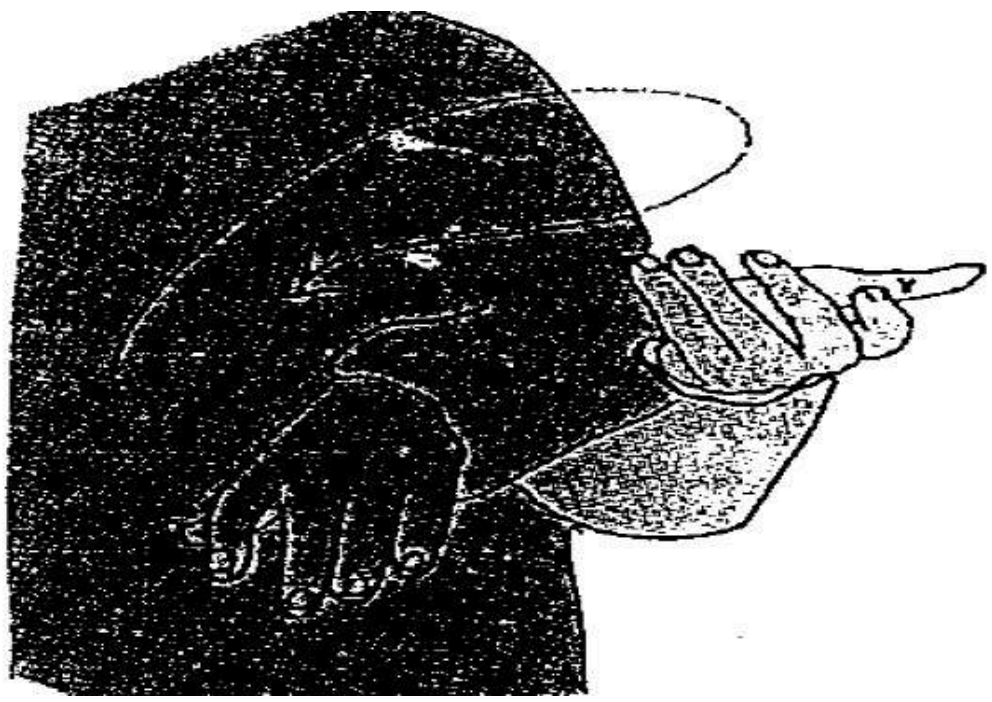

Seeking gestures serve to elicit responses from addressees, i.e. for seeking help, seeking agreement or seeking following (Bavelas et al., 1995: 397). As it has already been mentioned, a conduit metaphoric gesture can be used to seek help from the addressee's side, as if the speaker wanted the addressee to fill her/his hand(s) taking the form of a cup with the right answer or phrase (see Figure 4). The speaker may also want to seek the addressee's agreement; the equivalent paraphrase would be You know?, Don't you agree? (Bavelas et al., 1995: 396) or What else could I do? (Bavelas et al., 1992: 475). For these paraphrases, we can mention, for example, the gesture called palm lateral, where the open hand with palm up is moved laterally and often somewhat backwards [....] combined with a raising of the shoulders in a "shrug" and a certain range of characteristic facial expressions (Kendon, 2004: 265) (see Figure 1). The same gesture is also called open hand supine with lateral movement (Kendon, 2004: 275). Usually performed with both hands, this gesture refers to two opposing semantic themes depending on the communicative situation: an unwillingness to intervene with respect to something, or an inability to do so or something that is redundant and about which nothing further can be said (Kendon, 2004: 265). 10

Lastly, turn gestures are performed within issues around the speaking turn, where the speaker can give, take, forestall or open speech turns (Bavelas et al., 1995: 397). They have equivalent paraphrases such as Let me finish. Don't interrupt (Bavelas et al., 1992: 475) or else Your turn now, Who's going to talk next? (Bavelas et al., 1995: 397). Turn gestures thus usually include deictic dimension (see Figure 6): 


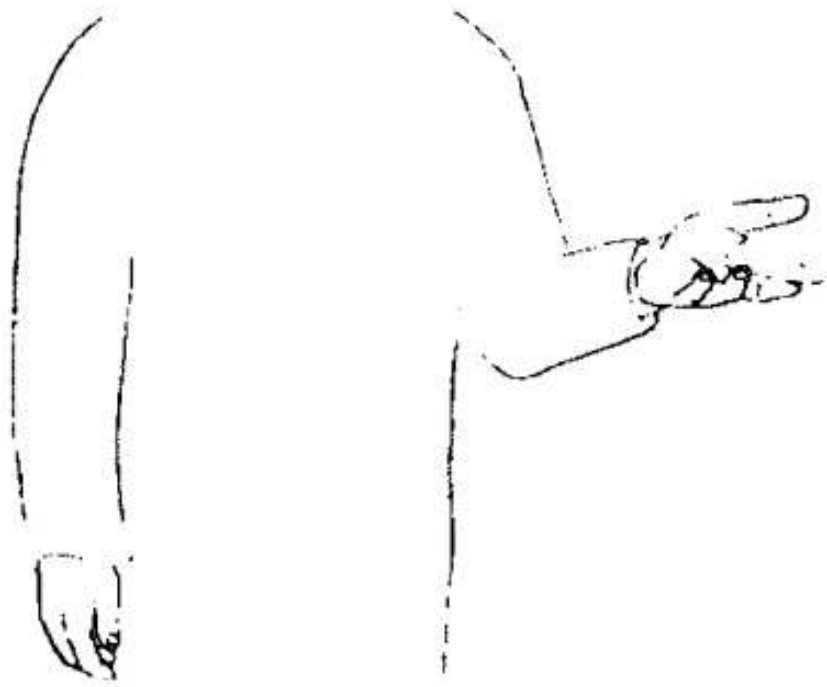

34 They can also include vertical palm gestures (Figure 3 above) that can be used for interrupting or forestalling the addressee's turn and in that case, it can be associated to a paraphrase such as Let me finish. Don't interrupt (Bavelas et al., 1992: 475).

In short, interactive gestures are a category of conversational gestures apart from emblems. They give no information about the topic and there is a paraphrased (implicit) reference to the interlocutor. To what extent does this definition apply to instructional context?

\subsection{Instructional contexts: a propitious setting for analyzing interactive gestures}

Tellier and Stam (2012) consider interactive gestures as an additional type of gesture along with McNeill's dimensional typology. Yet, we contend that those gestures need to be analysed not as a type/dimension but as a function. To do so, there is a need to come back to what makes the specificity of the classroom context at an interactional level.

\subsubsection{Specificities of classroom polyfocal polylogues}

While Bavelas et al. (1992: 469) stipulate that the most common setting for discourse is faceto-face dialogue, it may be interesting to turn to Goffman's notions of polyfocal interactions (1956) and participation framework (1981) in order to better understand the challenges of classroom interaction.

Goffman's (1956: 66) approach to interaction opened an enhanced window onto the complexity of social encounters; among other ideas, he sustained that many performances involve, as constituent parts, separate knots or clusters of verbal interaction. It 
challenged the traditional perception of interactions as being constituted of a unique locus of exchange to propose the idea that social encounters rather involved several foci of interactions. Moreover, some years later, Goffman (1981) called into question the traditional dyadic model and, since most encounters include more than two participants, he proposed to consider hearers as being members of the participation framework; consequently, there were no longer one speaker and one hearer. The notion of hearership is complexified, as it is deconstructed into a range of participants which include ratified and unratified participants (or bystanders) (Goffman, 1981: 132). Every contribution to the encounter is addressed to all members of the interaction, who then have a certain degree of participation status.

\subsubsection{Classroom interactions as polyfocal polylogues}

These models allowed a renewed analysis of classroom interactions and led to several complementary reflections. Bouchard (1998), for example, asserts that classroom interactions are polylogues consisting of three or more participants who may simultaneously speak; thus, they give way to overlapping exchanges that teachers should manage. ${ }^{11}$ As a matter of fact, when a teacher produces an utterance, her/his utterance has some metonymic dimension (Bouchard, 2005), inasmuch as though it may be addressed to one student, the other members of the audience are implicit addressees. Besides, the existence of polyfocal interactions in the classroom context requires from teachers the ability to pay attention to these several foci of conversation and to manage polylogal interactions. While research has shown that teachers deployed some sort of polyfocalisation aptitude (Rivière \& Bouchard, 2011; Filliettaz, 2002), Azaoui (2015a) showed how the interplay of gaze and hand gestures enabled instructors to deal with this polyfocalisation at an enunciative level; but it also offered the opportunity to maintain interpersonal and intersubjective relationship with several students simultaneously.

\subsubsection{Classroom context: a plurisemiotic environment}

40 A word needs to be said about another specific aspect of classroom interactions: their plurisemiotic dimension (Roth, 1999; De Saint-Georges, 2008). Indeed, interactions are situated within an environment that offers a range of semiotic materials extending inter alia from whiteboards, over-head projectors, posters to teaching books, which may manually be resorted to or referred to by using different modalities (hand gestures, orientation of gaze, verbal reference, etc.). Hence, teachers and students are apt to use these documents/materials to support their argument, to make their idea more explicit or to prompt answers. Consequently, even though these semiotic tools may not be considered as members of the interactions as such, they are structurally constituent of the exchanges and, therefore, may not be sidelined, when one is dealing with the issue of interactive gestures. This perspective, we assume, needs to be considered when deciding on the interactive function of teaching gestures.

\section{Methodology}

41 The operability of interactive gestures as defined by Bavelas et al. (1992, 1995) constitutes the main problematic of this research within the description of teacher 
gestures in language classroom. Secondly, the research aims to examine the adaptability of this gestural category to instructional contexts. Lastly, the possibility of a gradation between topic and interactive gestures is also discussed.

In the following lines, after presenting the participants and our coding scheme, we will come back into details to our reflections concerning the adaptation of the interactive gestures category to the classroom context.

\subsection{Participants}

In order to find the answers to our research questions, an ethnographic research strategy where the participant observer/ethnographer immerses him or herself in a group [...] observing behavior (Bryman, 2012: 432) was applied. As an ethnographic research usually entails a long period of time, our research could rather be qualified as microethnographic (Bryman, 2012). For example, in the case of French as a Foreign Language setting, the video recording time extends to a period of 3 months, where an approximately 500 minute of data was collected, of which a 45 -minute segment was used for this study.

The study group consists of two French school teachers teaching French in secondary schools in Turkey and in France within two different instructional contexts; those are respectively French as a Foreign Language taught to Turkish students of French in Turkey ${ }^{12}$, and French as a Second Language taught to newly arrived migrants who had been schooled in France ${ }^{13}$ for at most one year at the time of the video recordings. ${ }^{14}$ The language proficiency level of the students in Turkey and in France was respectively A1 and $\mathrm{A} 1-\mathrm{A} 2^{15}$. The data was collected empirically through the video recordings of two French sessions (duration of 45 minutes for each instructional context) within natural classroom settings.

\subsection{Coding and counter-coding}

The transcription of teachers' utterances and the annotation of their gestures were carried out on ELAN (Sloetjes \& Wittenburg, 2008). In total, 92 minutes of videorecorded corpora were analysed and 739 gestures coded. Four gestural tiers were composed via the controlled vocabulary on ELAN (see Figure 7): The first tier "Type" is the gestural dimension according to McNeill's (1992) gestural categorization. However, we also included emblems in the first tier, when considering the instructional context. The second tier "Conv_Gest_1" is the type of conversational gesture where the codes "Topic 1" and "Interactive 1" were the two choices. In case a gesture would adhere to both options, a third tier called "Conv_Gest_2" was also included with Topic 2 and "Interactive 2" as the possible codes. The final tier "Inter_Subf" was reserved for the subfunction of a gesture, when it had an interactive function ("Interactive 1" or "Interactive 2"); thus, "Delivery", "Seeking", "Citing" and "Turn" were the coding alternatives for these cases. 
Figure 7. Snapshot of the annotation window on ELAN

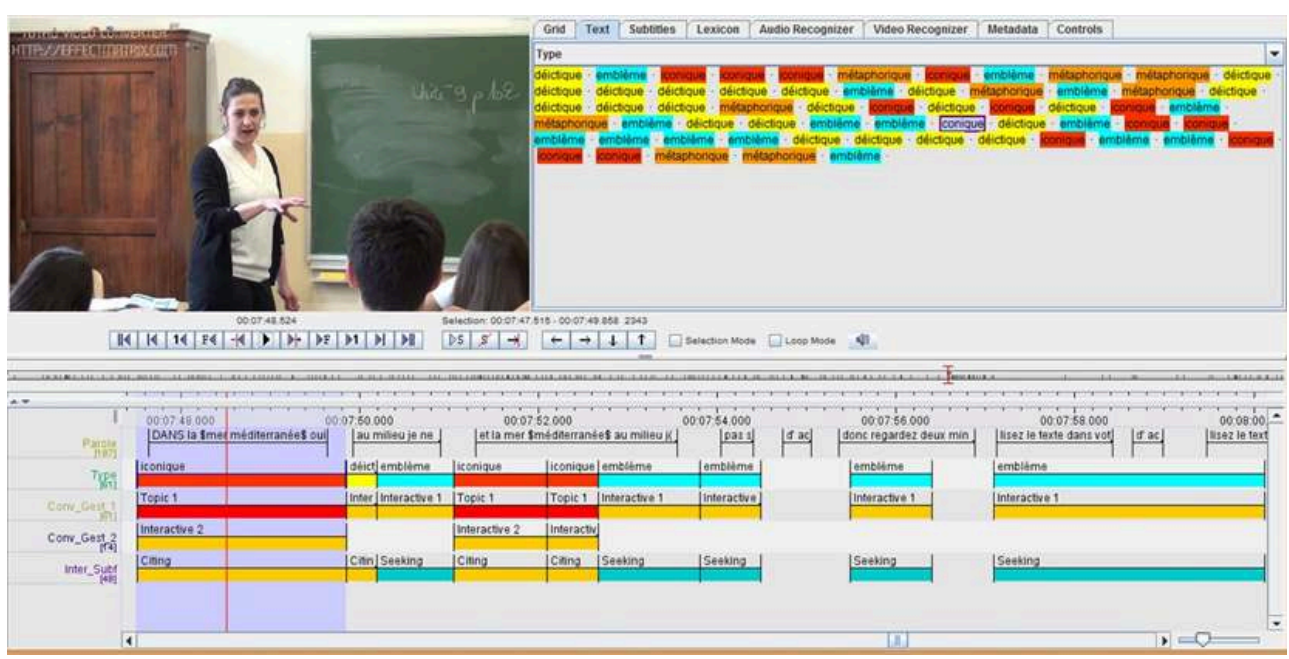

For the purpose of verifying the reliability of the coding and measuring the agreement rate, the first 15-minute sequence of a 47-minute corpus was counter-coded by the annotator who had not initially annotated it. ${ }^{16}$ Out of the 128 annotated gestures, the results of the counter-coding show $71 \%$ of matching answers between the two annotators. We also calculated the Unweighted Kappa for the reliability of the countercoding and found $\kappa=0.42$ : This value corresponds to a moderate matching level between the two annotators and is acceptable according to Landis-Koch (1977) scale (as cited in Santos, 2019: 3).

\section{Results and discussion}

47 We shall start with a quantitative presentation of the results before analyzing them on a more qualitative basis.

\subsection{Quantitative results}

48 The quantitative analysis will help us see the distribution of gesture interactive/topical functions in the two instructional contexts.

\subsubsection{French as a foreign language}

During the 45 minutes of interaction, 336 gestures were coded. Out of these 209 (62\%) were interpreted as interactive gestures, while $127(38 \%)$ were coded as topic gestures. Hence, the majority of the gestures performed are interactive and they are operable in the context of teaching French as a foreign language (FFL).

As far as the subfunctions (concerning uniquely the tier "Conv_Gest_1") of interactive gestures are concerned, the distributions are given below in Table 2. We see that interactive gestures can assume all subfunctions proposed by Bavelas et al. $(1992,1995)$ in this instructional context. However, citing and seeking subfunctions acquire greater percentages than the other ones. 
Table 2. Frequencies and percentages of interactive subfunctions in FFL context

\begin{tabular}{|l|l|l|l|}
\hline Citing & Delivery & Turn & Seeking \\
\hline $74(35 \%)$ & $18(9 \%)$ & $44(21 \%)$ & $73(35 \%)$ \\
\hline
\end{tabular}

51 Table 3 below shows the distribution of each subfunction according to the gesture dimension. Considering the results, all gesture categories can take over an interactive function. Especially, deictic and emblematic gestures are mostly used for interactive purposes. Furthermore, contrarily to Bavelas et al.'s (1992, 1995) conception of interactive gestures, emblematic and iconic gestural dimensions may have an interactive function as well (to be examined in $§ 4.2$ ).

Table 3. Distribution of each subfunction according to gestural dimension in FFL context

\begin{tabular}{|l|l|l|l|l|}
\hline & Deictics & Metaphorics & Emblems & Iconics \\
\hline Citing & 61 & 2 & 11 & 0 \\
\hline Delivery & 0 & 4 & 14 & 0 \\
\hline Seeking & 5 & 20 & 48 & 0 \\
\hline Turn & 27 & 0 & 9 & 8 \\
\hline TOTAL & 93 & 26 & 82 & 8 \\
\hline
\end{tabular}

\subsubsection{French as a second language}

During the 47 minutes of the interactions under study, 403 gestures were coded. Out of these, 229 (57\%) were interpreted as interactive gestures, while 174 (43\%) were coded as topic gestures. Thus, the majority of the gestures performed are interactive and they are operable in the context of teaching French as a second language (FSL).

As far as the subfunctions (concerning uniquely the tier "Conv_Gest_1") of interactive gestures are concerned, the distributions are given below in Table 4. We see that interactive gestures can assume all subfunctions proposed by Bavelas et al. $(1992,1995)$ in this instructional context. Compared to the first instructional context, the subfunction percentages are rather more evenly distributed.

Table 4. Frequencies and percentages of interactive subfunctions in FSL context

\begin{tabular}{|l|l|l|l|}
\hline Citing & Delivery & Turn & Seeking \\
\hline $65(28 \%)$ & $59(26 \%)$ & $53(23 \%)$ & $52(23 \%)$ \\
\hline
\end{tabular}


Furthermore, Table 5 shows below the distribution of each subfunction according to the gesture dimension. As in the first instructional context, these are mostly deictic and emblematic gestures, which are produced for interactive purposes.

Table 5. Distribution of each subfunction according to gestural dimension in FSL context

\begin{tabular}{|l|l|l|l|l|}
\hline & Deictics & Metaphorics & Emblems & Iconics \\
\hline Citing & 63 & 0 & 2 & 0 \\
\hline Delivery & 6 & 24 & 29 & 0 \\
\hline Seeking & 34 & 2 & 17 & 0 \\
\hline Turn & 27 & 0 & 25 & 0 \\
\hline TOTAL & 130 & 26 & 73 & 0 \\
\hline
\end{tabular}

\subsection{Qualitative results}

55 The qualitative analysis will now help refine our understanding of interactive gestures within the specific context of the classroom.

\subsubsection{Degrees of interactivity and topicality}

Seeking in a classroom context mostly takes place around classroom management activities such as instructions, question-answer activities, appealing to a specific verbal contribution or nonverbal action (i.e. a change in the attitude) on the learners' side. In a typical seeking response sequence, the teacher points her forefinger to a student. In Figure 8 for instance, the teacher explicitly wants the student to answer her question: "C'est c'est quoi une technicienne, tu le sais Otman?" ("What, what is a technician, do you know that Otman?"). She indicates who her interlocutor is by pronouncing his name and by pointing her forefinger at him. By doing so, the student and the rest of the class know that she is expecting a response only from him. ${ }^{17}$

"C'est c'est quoi une technicienne, tu le sais Otman?" 
Figure 8. Example for requesting an answer via a deictic gesture in FSL

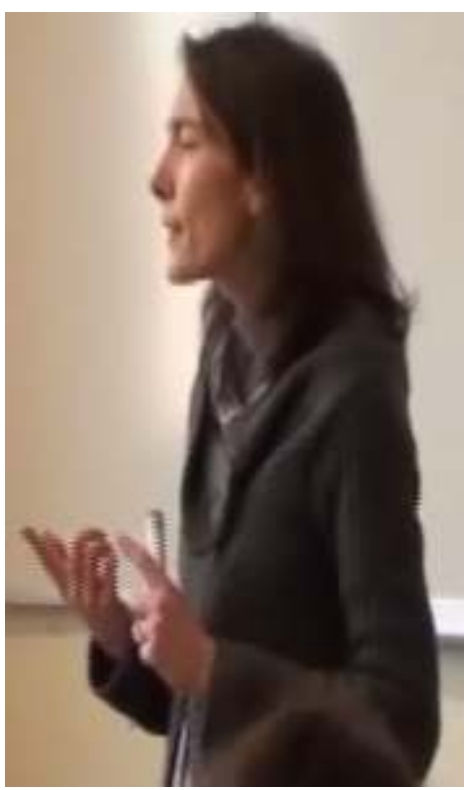

Or else, the teacher may produce a metaphoric gesture that would present to the students an imaginary container they have to fill in with an answer (in that case, the gesture would be interactive, as in Figure 9). Differentiating between a topic and an interactive gesture proves to be crucial. For example, the teacher from our Turkish corpus asks a question about the topic/theme of the unit (treated within the course book) via a conduit metaphoric gesture (see Figure 9): "Quel thème est abordé?" ("What theme is tackled [in the unit]?").

"Quel thème est abordé?"

Figure 9. Example for seeking an answer via a metaphoric gesture in FFL

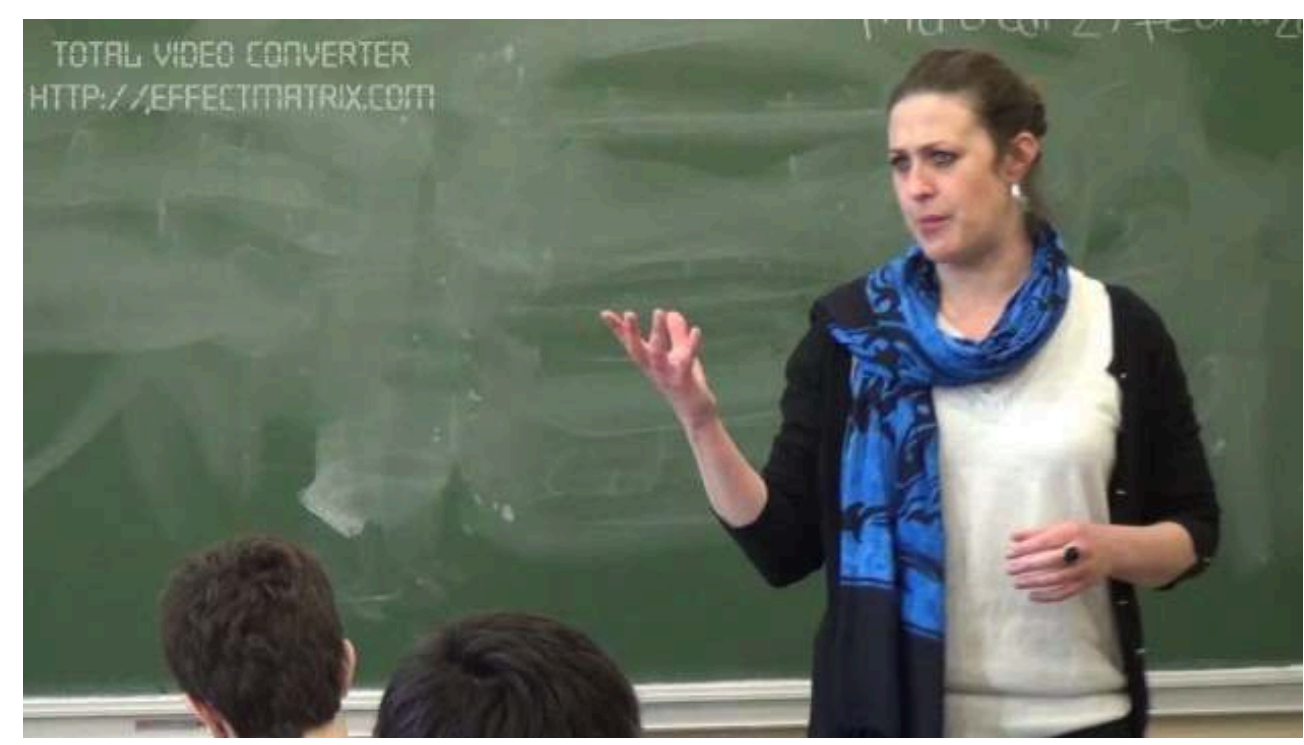

Following Calbris's (2011: 163) idea of polysign which she defines as a gesture that expresses several notions simultaneously on one occasion of use, we believe such deictic or metaphoric gestures accompanying questions in the examples above might consider a 
continuum allowing to think in terms of degree of topicality/interactivity, rather than either topic or interactive gestures.

In the subsequent sequence we might also consider the possibility of a continuum. As the students do not reply to the teacher's question, the latter feels the need to clarify her question by repeating "en général" ("in general"), where she performs a metaphoric gesture which depicts a kind of frame (illustrating metaphorically the big picture of the unit concerned); she draws the frame in the air and finishes her gesture by directing her two hands towards the students (see Figure 10).

“En général, en général"

Figure 10. Example for a gesture having double function in FFL

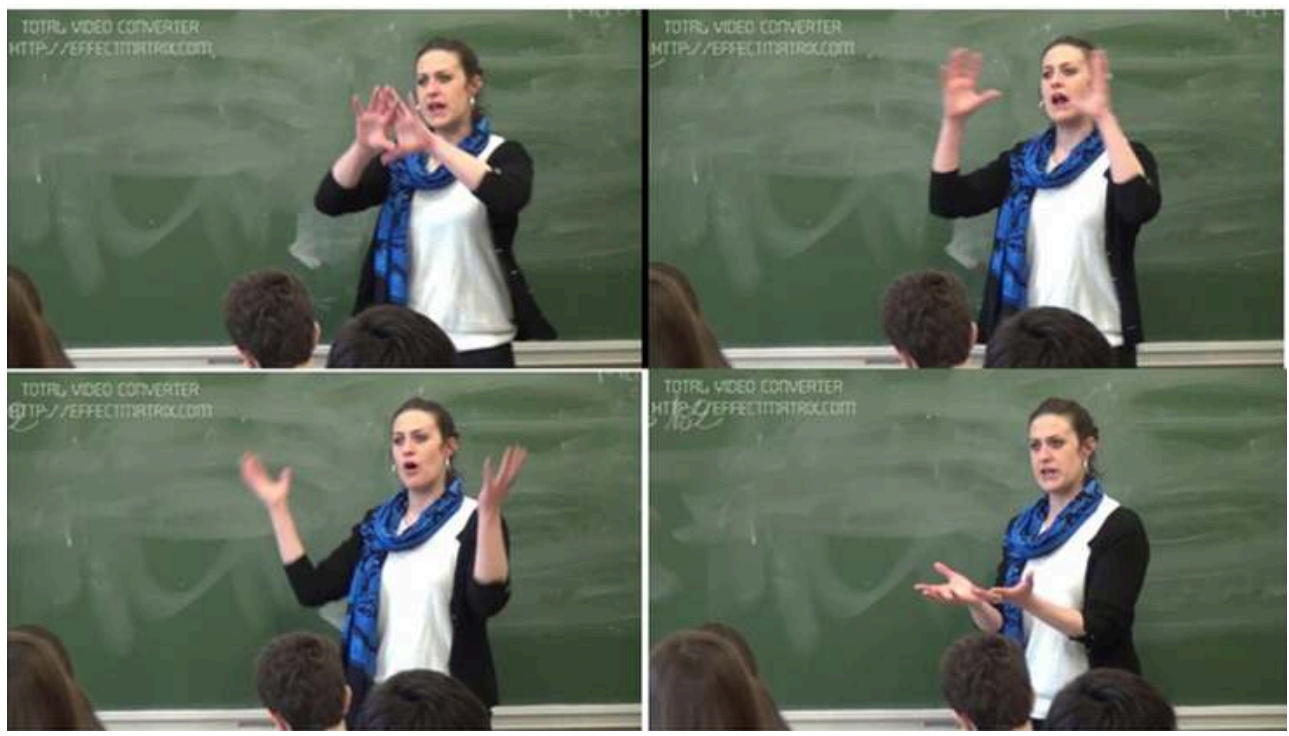

Here, it seems that the main objective is to disambiguate either the word "theme" or the entire question. That is why the first function is a topical one, as she illustrates the referent "in general". However, the directing of the two hands at the end of the gesture means also the expectancy of an answer from the students. The corresponding paraphrase could be for example: "What is the theme in general according to you?"

\subsubsection{Emblems as possible interactive gestures}

Bavelas et al. $(1992,1995)$ distinguish emblematic gestures as a separate category with respect to conversational gestures. However, we aver that emblems (or hand signals) constitute a dimensional gesture category and not a functional one. Moreover, as emblems are thoroughly pragmatic (Payrató \& Teßendorf, 2014: 1532), in the absence of the utterance, they fulfill its pragmatic functions and when they co-occur with it, they amplify its pragmatic/illocutionary function (Colletta, 2005; Coquet, 2012). They may thus serve various roles. For example, one of the teaching emblems ${ }^{18}$ frequently used in classroom contexts is the one referring to repetition or to continuity. In order to ask a student to repeat her answer, the teacher flicks her forefinger outwards and rotates it quickly towards herself with a spiral/circular motion (see Figure 11). 
Figure 11. Example for an interactive pedagogical emblem in FFL

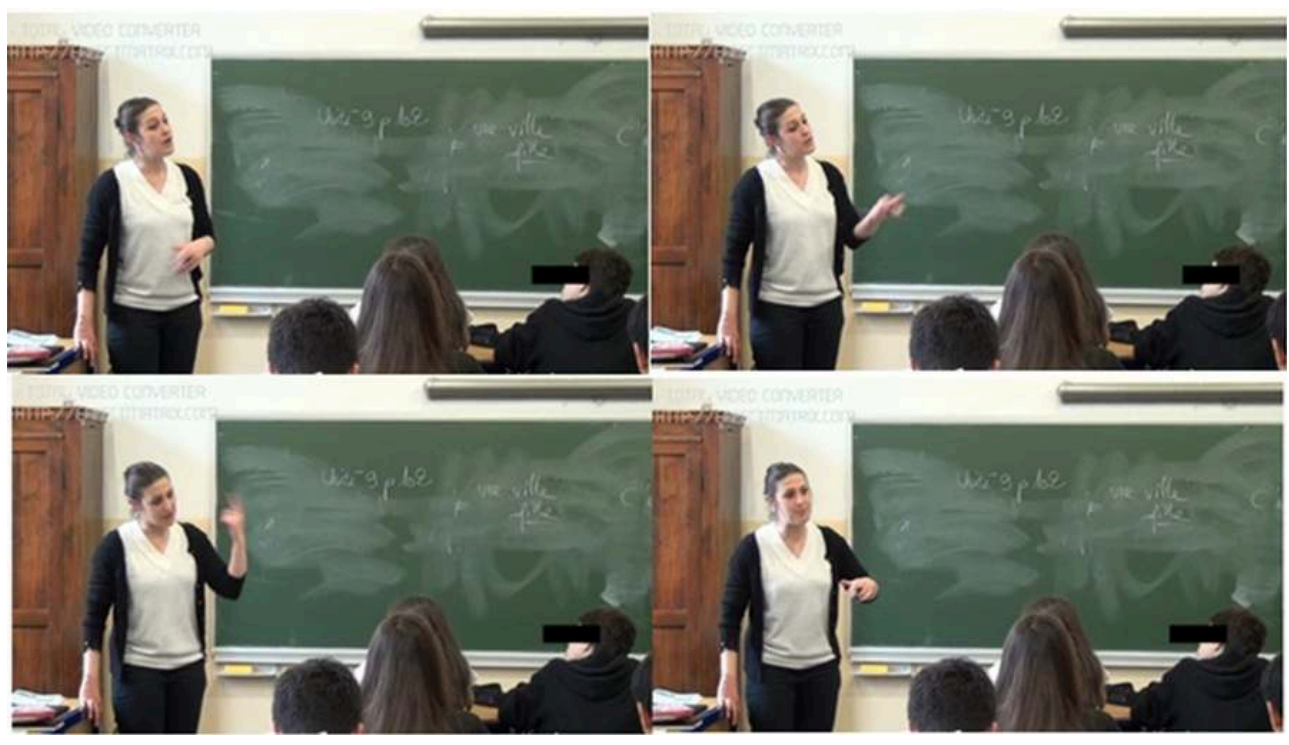

According to Calbris \& Montredon (1986: 28), by having a somehow fixed meaning and by tending to being performed in any geometric plan, this gesture metaphorically illustrates returning to a previous point in the course of a discussion ${ }^{19}$. In our example, the teacher also verbalizes the French word "répète" ("repeat"). Yet, the gesture is not mainly produced to clarify the meaning of the word; instead, as an instruction, it is almost an automatic movement destined to create a particular reaction on the addressee's side. So, and although it is redundant to speech, it intensifies the word and has an illocutionary (for the speaker)/perlocutionary (for the addressee) value. Hence, it is interactive in our point of view. This idea is somehow supported by Kendon (2004: 339), when he states that emblems (in his terminology quotable gestures) can be used for interpersonal control.

Therefore, some interactive emblems are prone to bear a seeking subfunction by stimulating a particular response on the students' side (that is why it is not simply about turn coordination). It also means that seeking gestures do not necessarily involve help, agreement or following but they can relate to any speech act such as a request for repeating something in this instance.

Another gesture which may be qualified as emblematic and interactive is the palm lateral gesture mostly accompanied with a shrug and a facial expression (already mentioned in the theoretical framework) (see Figure 12).

“Un guide? C'est aussi possible." 
Figure 12. Palm lateral gesture as an interactive emblem in FFL

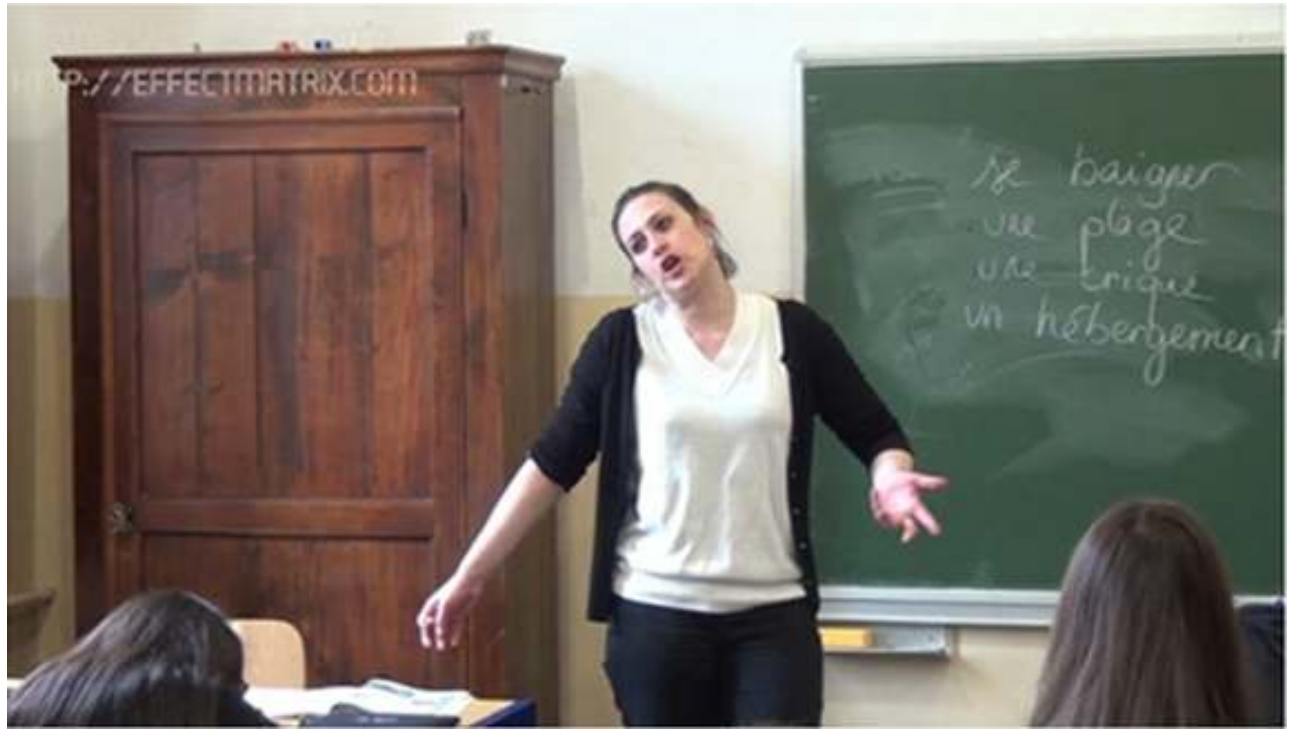

This widespread gesture -accepted by some researchers as an emblematic gesture (Calbris \& Montredon, 1986: 80; Morris, 1997: 138) - generally marks two semantically different meanings: disavowal, lack of knowledge, incapacity to do something but also something undeniable or obvious; whatever its usage, two paraphrases are implied: Isn't it so? or Who knows?. In all instances, an implicit seeking for agreement is expressed. For example, while examining the difference between "guide touristique" ("travel guide") and "catalogue de séjour" ("tour operator's guide"), a student says that there are images on a tour operator's guide. Then, the teacher explains that it is also possible to have images on a tourist guide: "Un guide? C'est aussi possible." ("A guide? It is also possible."). At the same time, she produces the palm lateral gesture for marking obviousness and therefore, she seeks agreement.

The corpus displays a recurrent usage of another gesture where all fingers are curled except the forefinger, which is extended and directed upwards (see Figure 13).

"Écoute-moi!" 
Figure 13. Extended forefinger produced for seeking attention in FFL

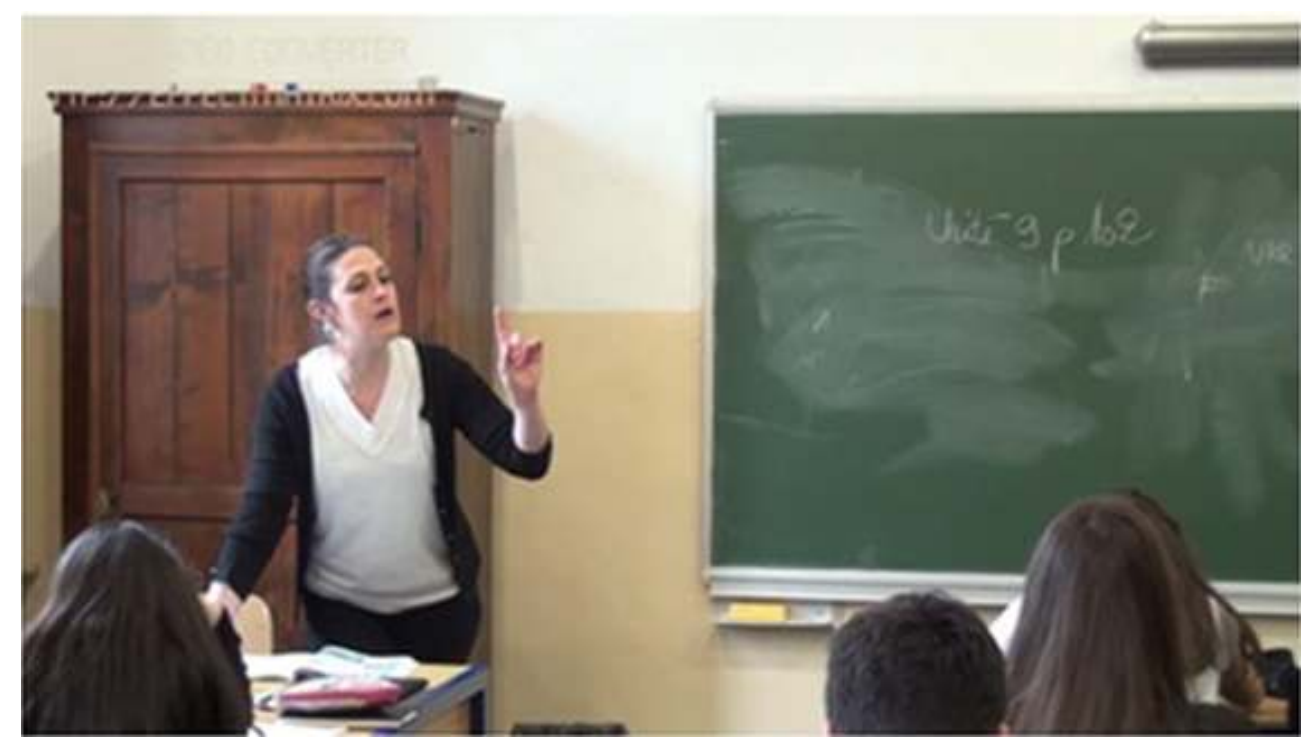

The pedagogical objective of this gesture is not the topicalization of the referent “Écoute-moi!" ("Listen to me!"). This nomination deictic (Kendon, 2004: 142) embodies a speech act, where the instruction (illocutionary value of the gesture) is supposed to be obeyed by the student concerned (on the perlocutionary level). It is claimed to be universal (and then emblematic) by Morris (1997: 105) and means Listen to me carefully! We might think of this gesture as a means to attract the attention of the interlocutor; therefore because it is performed mostly for seeking attention, this emblem may be categorized as interactive.

\subsubsection{Citing teaching material}

68 Within a typical general citing situation in instructional contexts, teachers direct their finger(s) or hand(s) to a student, to a group of students or to the classroom in order to refer to a point previously mentioned/shared. In those circumstances, abstract deictic interactive gestures (McGowan, 2010) are rather performed. This situation is exemplified in Figure 14: Here, the teacher reacts to a student's utterance ("Magasin d'Europe") by repeating it on the verbal channel and by performing simultaneously a deictic gesture pointed towards the student but referring to the student's utterance (hence approving the previous verbal contribution of the student about the topic of conversation). Moreover, although the teacher's right forefinger is directed towards the student, her gaze is not, because she is simultaneously cleaning the blackboard. There is an orchestration of two simultaneous teaching activities, as it is often the case in instructional classrooms (Rivière \& Bouchard, 2011; Azaoui, 2015a).

“Magasin d'Europe, ah, ça m'est pratique, je peux négocier...”

("Europe shopping mall, ah, it is practical to me, I could negotiate there...") 
Figure 14. Example for citing a student's contribution in FFL

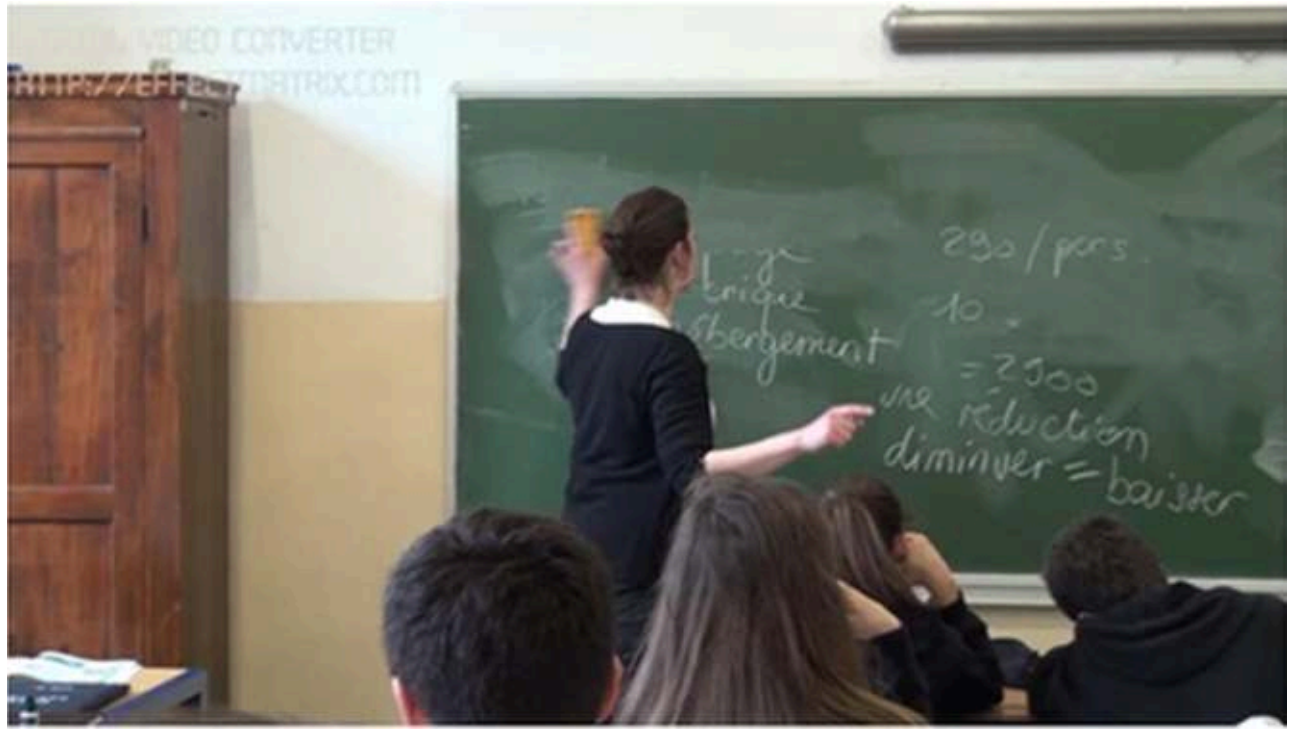

However, since different semiotic tools at the teachers' disposal may come into force for practical reasons (e.g. to gain time and proceed to the next activity), observations show that teachers do not only cite students' verbal contributions but also other semiotic/pedagogical materials. For example, a student asks the teacher a question whose answer features in the text they have been studying since the beginning of the session. Then, the teacher, knowing that the student's question will be elucidated through the reading of the excerpt under study, directs her forefinger towards the text/course book (see Figure 15): "On va lire..." (“Let's read [that excerpt]...").

"On va lire..."

Figure 15. Example for citing the course book in FFL

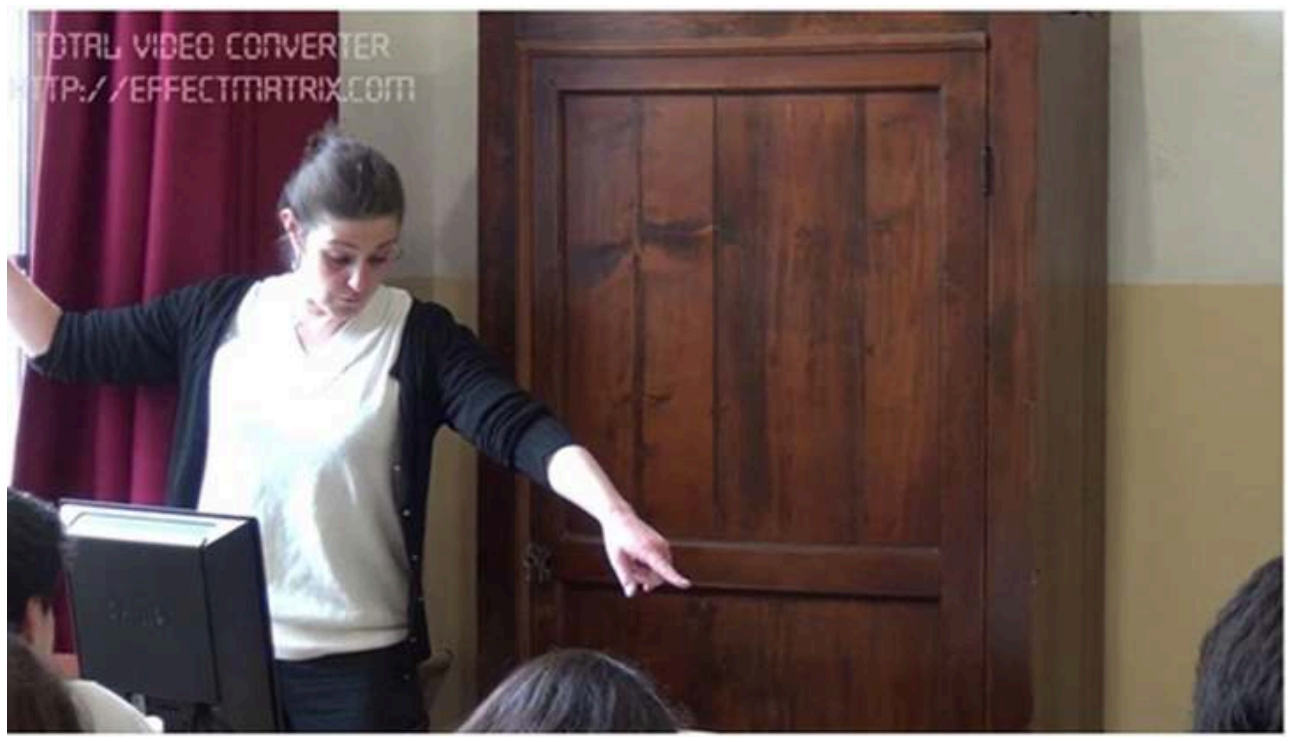

In our point of view, the gesture does not actually give any clarifying information about the answer (and so, the gesture is not topical) but refers back to the excerpt at a discursive and dialogic level, i.e. to an element already shared by participants within 
the classroom interaction. In this instance, the corresponding paraphrase of the gesture could be: "Look at the text that we are studying and after we read it, you will understand". In fact, as Johnston (2013: 110) puts it, pointing as a communicative act is also prone to being used to help retrieve (or signal as retrievable) some entity or location, i.e. to indicate that some entity or location is known or knowable because it has been previously mentioned or is assumed to be part of shared knowledge. Hence, unless the gesture is about a newly made point or produced for clarification purposes, we consider this kind of gestures as interactive. When the teacher points towards the excerpt (or any element on the blackboard, a document, a teaching material, etc. in general) for citing purposes, her gesture does not solely engage the student concerned but the whole class so that they find their way in case they have missed something or been lagging behind.

Likewise, in Figure 16 the teacher is no longer the source of the information and she only needs to point at the board (where the following rule is written: "Interdit de se disputer, de se moquer!" ("It is forbidden to quarrel and make fun of others!"), which literally materializes the joint construction of knowledge: "Euh, donc ça, je veux pas, hein?" ("So, I don't want this [to happen], right?").

“Euh, donc ça, je veux pas, hein?"

Figure 16. Citing the whiteboard in FSL

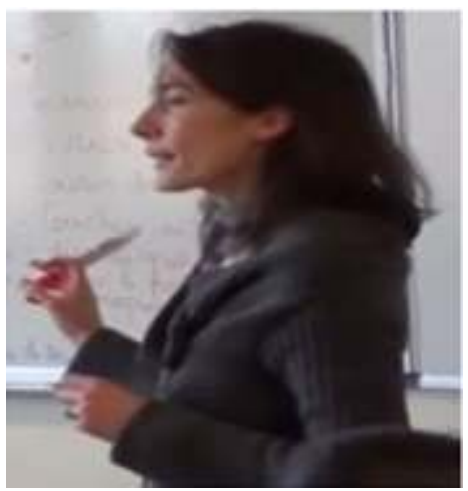

This silent scaffolding (Bouchard, 1998) facilitates self-correction, as it teaches the students to be autonomous in the retrieval of some information they have been manipulating altogether.

This illustration is interesting also because it shows some interplay between gaze and deictic gesture. While the teacher's gaze is oriented towards her interlocutors, her gesture draws the attention of the students towards the focus of interest. It helps her minimize her verbal information "Ça, je ne veux pas." ("I don't want this to happen."), since the pronoun's referent is made explicit by the sentences previously explained and written on the board.

\subsubsection{Activity coordination as a part of turns}

74 As shown in Figure 17 below, while forestalling a turn with a hand gesture, the teacher gives turn via her gaze. Azaoui $(2014,2015 \mathrm{a})$ coined the expression co-enunciative ubiquity to refer to the ability of a teacher to resort to multimodal resources to be the interlocutor of several students simultaneously. In this example, while the vertical palm gesture produced by the teacher signals a student not to interrupt her interaction 
with another student, the teacher simultaneously gives turn to the latter via gaze and speech (she pronounces the student's name, "Deniz"). The concurrent interplay of hand gesture and gaze allows the teacher to orchestrate simultaneous interactions.

“Deniz?”

Figure 17. Example for simultaneously forestalling and giving a turn in FFL

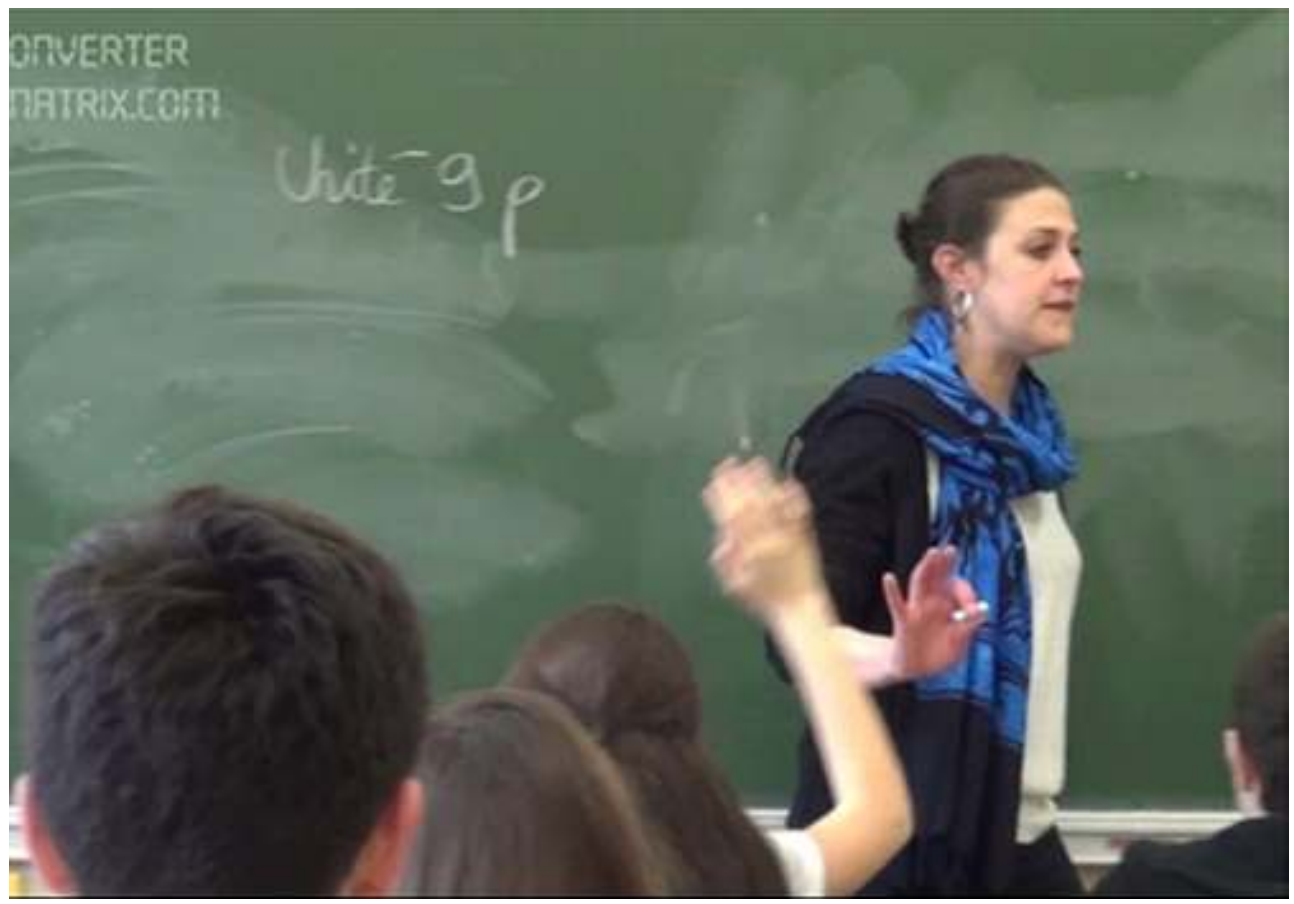

Moreover, Figure 18 shows that in order to invite a student ("Batuhan") to the blackboard, the teacher produces a polysign gesture (Calbris, 2011: 163).

“Uhm, Batuhan!”

Figure 18. Example for activity coordination in FFL

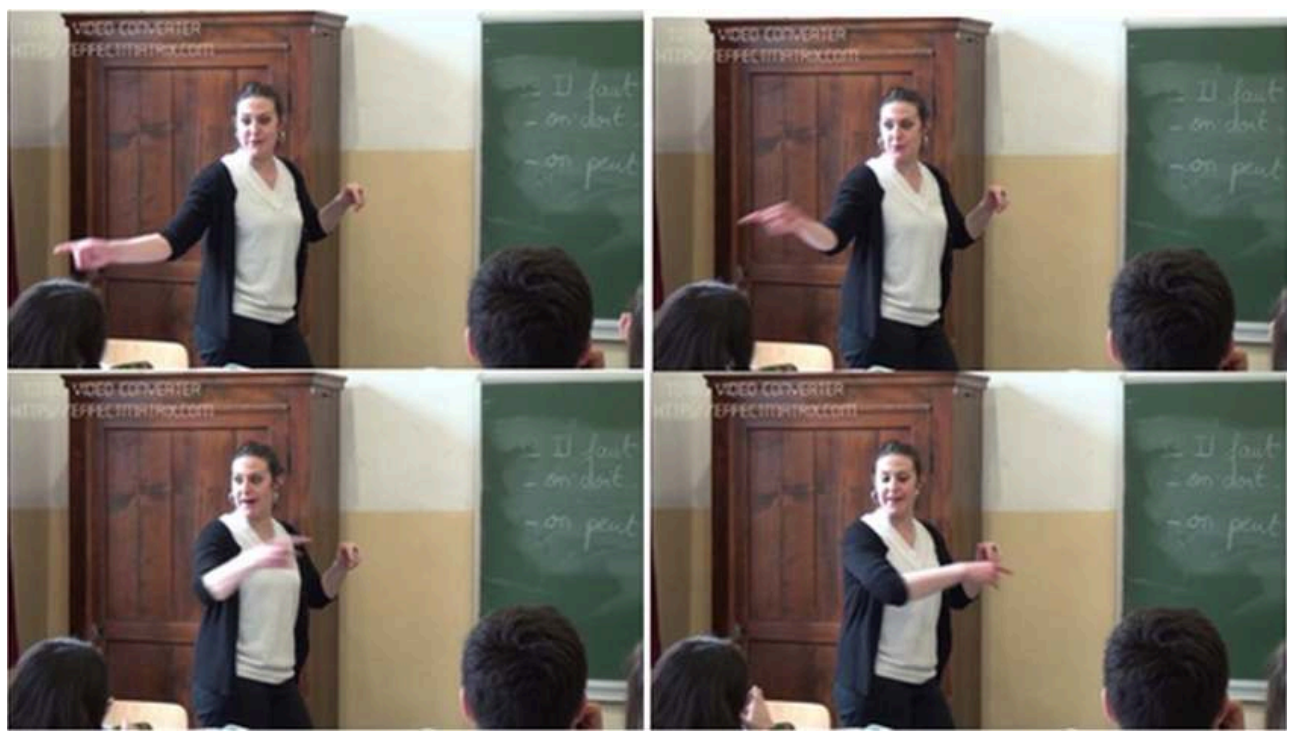

TIPA. Travaux interdisciplinaires sur la parole et le langage, 36 | 2020 
This gesture is in fact a mixture of two brief deictic gestures (the first one pointing towards the student and the other one towards the blackboard) and an iconic gesture depicting the act of moving (for this, the teacher sweeps the air via her index finger). Some variants of this gesture (carried out with the index or the whole hand in different geometric plans) are used worldwide; it is considered as a unique gesture and an emblem by Morris (1997: 98 \& 147). Therefore, when considering the communicative/ interactive specificities of instructional contexts, it is possible to conceive turn gestures, in a wider perspective, as activity coordination gestures.

\subsubsection{Withdrawal as a part of the delivery subfunction?}

77 As already mentioned, conduit metaphor gestures are considered by Bavelas et al. (1992: 472) as interactive gestures, as [they] treat the words or information being conveyed as an object transmitted between the interlocutors. So, the information delivery function is mostly undertaken by various forms of conduit metaphoric gestures. For instance, while explaining private beaches where people pay entrance fee, the teacher performs subsequently two conduit metaphoric gestures (see Figure 19, frames a and b): "payantes, privées" (“chargeable, private").

Figure 19. Example for delivering information in FFL

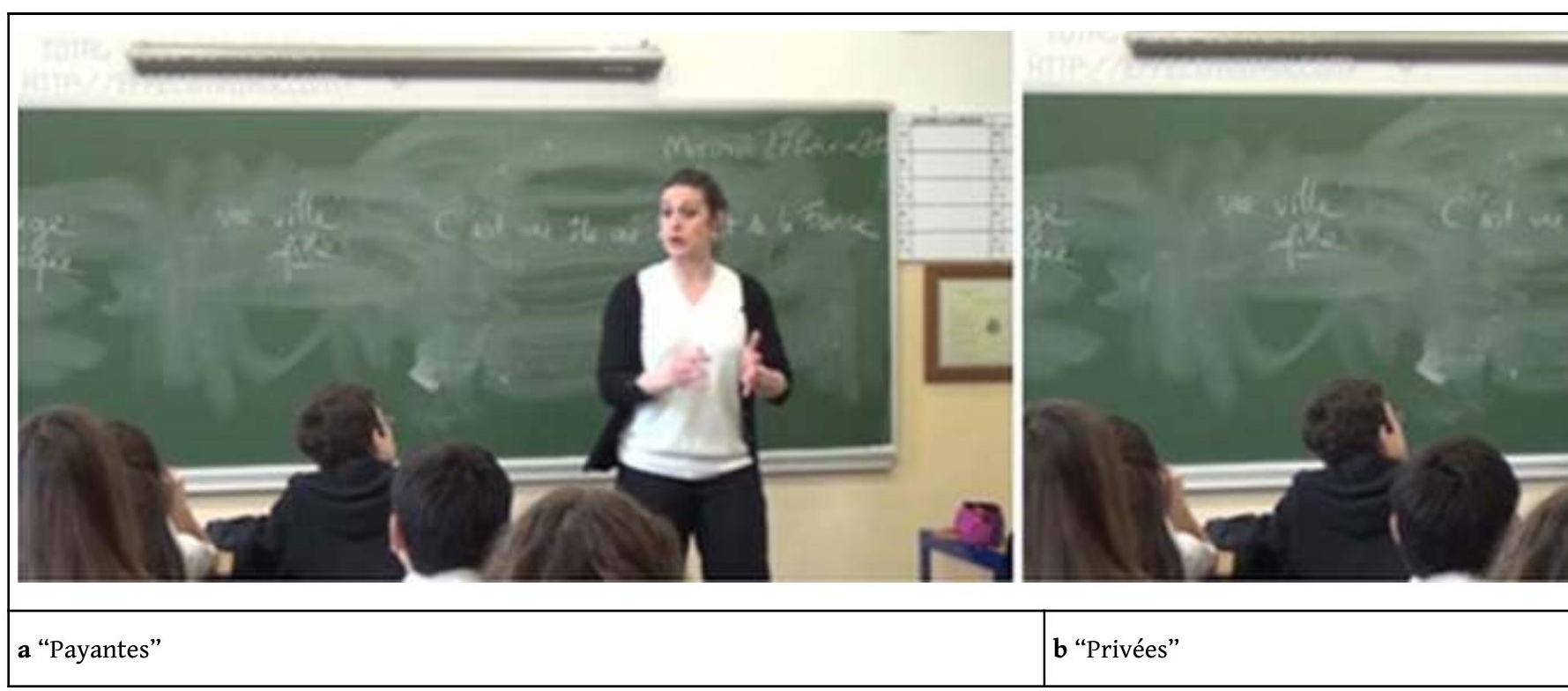

78 Here, the theme of the discourse (i.e. the two abstract adjectives) is presented as objects to the students. Besides, the shape of the conduit metaphoric gestures is not destined to clarify the semantic content of the verbal referents but rather to depict them as contained objects.

If we consider the flip side of the coin in relation to delivery, we can claim that gestures related to withdrawal/rejection may also be regrouped under gestures charged with the delivery subfunction. For example, the teacher asks a student where swimming could be possible in Corsica according to the text they are studying. When the student answers that it is possible to swim in a pool, the teacher rejects the answer by a slightly 
waved left vertical palm (see Figure 20): "À la piscine? Dans le texte, ce n'est pas écrit à la piscine." ("In the swimming pool? It is not written in the text.")

"À la piscine? Dans le texte, ce n'est pas écrit à la piscine."

Figure 20. Example of a delivery gesture related to rejection in FFL

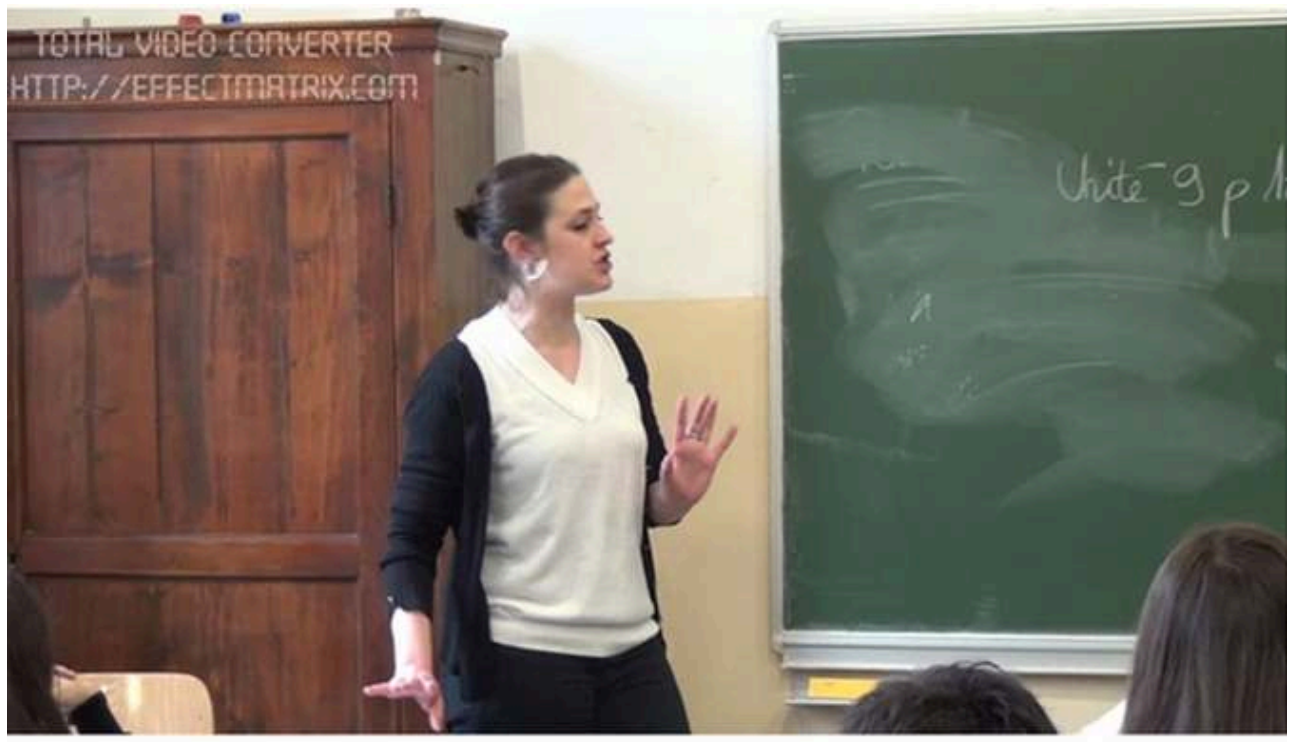

Here, the corresponding paraphrase could be "I do not deliver you that information [the information that they swim in a pool in Corsica, according to the text]".

\subsubsection{Two-handedness and interactive gestures}

81 Polyfocalisation, we said, was one of the classroom interaction specificities. Dealing with various foci of interaction or various semiotic materials requires some gestural ability; this phenomenon has been coined two-handedness by Azaoui (2015a). The two hands may produce two different dimensions and serve two separate teaching functions. Our analysis of interactive gestures allowed us to observe such situation (Figure 21).

“Oui, alors la deuxième chose que tu as dite Martine..."

Figure 21. Example of two-handedness on the interactive level in FSL

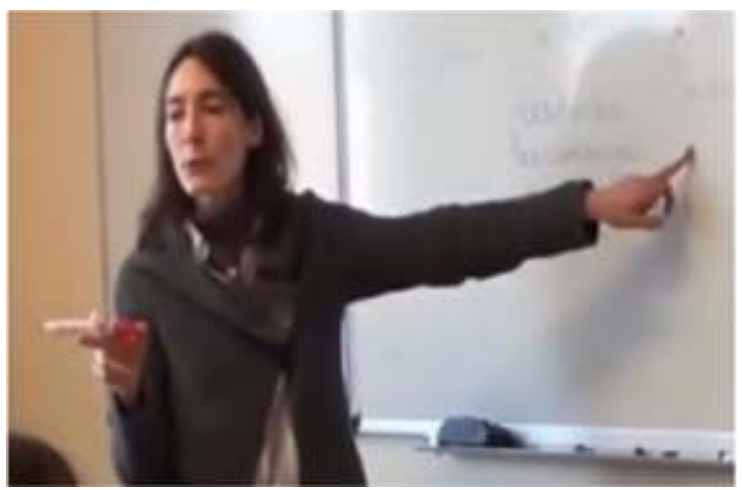

TIPA. Travaux interdisciplinaires sur la parole et le langage, 36 | 2020 
With her left hand forefinger, the teacher has been drawing the students' attention to the board, to organize the following activity. While keeping her left forefinger oriented to the whiteboard, she points to a student to ask her to repeat something she previously said: "Oui, alors la deuxième chose que tu as dite Martine..." ("Ok, so the second idea you mentioned Martine..."). Therefore we contend that the teacher performs two distinct interactive gestures simultaneously: citing gesture (left hand) and turn gesture (right hand). The latter serves the activity coordination while the former may have two complementary functions: citing the student, the pointing serving as a paraphrase "as you said earlier" and seeking a response from her. The teacher implicitly invites Martine to repeat the answer she previously gave.

\section{CONCLUSION}

We have proposed to examine Bavelas et al.'s $(1992,1995)$ conception of interactive gestures within two naturalistic instructional contexts (French as a foreign language and French as a second language), where interactions between teachers and students have their own specificities.

The results show that (1) the majority of the teachers' gestures have interactive functions, and (2) that especially, deictic and emblematic gestures may be charged with this function. In this perspective, and conversely to Bavelas and her colleagues' study, our analysis of some teaching emblems led us to the conclusion that emblematic gestures may also function as interactive gestures.

Besides, the qualitative analysis shows that, to a certain extent, a gesture may simultaneously be topical and interactive; therefore, rather than making a clear categorical distinction between these two dimensions, we consider that viewing them as parts of a continuum that would refer to a certain degree of topicality/interactivity may be theoretically more relevant. However, further research is required to delve into this problematic.

Moreover, contrary to Bavelas et al.'s $(1992,1995)$ results, in our study, interactive gestures may not necessarily be directed towards the addressee for several reasons. Classroom interactions being polylogal and plurisemiotic, interactive gestures may be oriented to other entities (participants or materials) than the ratified interlocutor. Our corpora show that teachers may also point to a teaching material (the blackboard, the course book, etc.) for citing a point previously mentioned by the group, which could be paraphrased as "as we said earlier". Similarly, in the case of emblems such as extended forefinger used for seeking attention, although the gesture is not directed towards the addressee, it is performed for interactive reasons and may thus be interactive.

When it comes to subfunctions, our analysis suggests that the seeking subfunction may also comprise the act of prompting a particular response on the students' side. Additionally, delivery gestures do not only concern the presentation of an idea but they may also express withdrawal or rejection. Furthermore, turn coordination involves, for us, both the gestures regarding speech turns and the ones regulating some role play activities or some tasks to be realized at the black/whiteboard.

All in all, this study has several broader implications. It stresses the need to implement Bavelas et al.'s interactive gestures category in the light of other situations that have specific interactional dimensions such as multiparty meetings (Mondada, 2013) or 
multiple participant interactions in desktop video conferencing. Because of its inner complexity on the interactional level, the instructional context lends itself to do so. Lastly, the understanding may also benefit from the study of other types of gestures, considered in a broader approach including other body parts that participate in the interactive process such as head movements or gaze orientations (Hadar et al., 1984; Goodwin, 2000).

\section{BIBLIOGRAPHIE}

Alibali, M. W., Evans, J. L., Hostetter, A. B., Ryan, K. \& E. Mainela-Arnold (2009) Gesture-Speech Integration in Narrative. Are Children Less Redundant Than Adults?, Gesture, 9, 3, p. 290-311.

Allen, L. Q. (1999) Functions of Nonverbal Communication in Teaching and Learning a Foreign Language, The French Review, 72, 3, p. 469-480.

Allen, L. Q. (2000) Nonverbal Accommodations in Foreign Language Teacher Talk, Applied Language Learning, 11, 1, p. 155-176.

Azaoui, B. (2013) One Teacher, Two Instructional Contexts. Same Teaching Gestures? TiGeR: Tilburg Gesture research meeting Proceedings, Tilburg, Netherlands, p. 1-4.

Azaoui, B. (2014) Multimodalité des signes et enjeux énonciatifs en classe de FL1/FLS, in Tellier, M. \& L. Cadet (eds) Le corps et la voix de l'enseignant: mise en contexte théorique et pratique, Paris: Éditions Maison des Langues, p. 115-126.

Azaoui, B. (2015a) Polyfocal Class Interactions and Teaching Gestures. An Analysis of Nonverbal Orchestration, Proceedings of the $4^{\text {th }}$ Gesture and Speech in Interaction (GESPIN) international conference, Nantes, France, p. 25-31.

Azaoui, B. (2015b) Fonctions pédagogiques et implications énonciatives de ressources professorales multimodales. Le cas de la bimanualité et de l'ubiquité coénonciative, Recherches en Didactique des Langues et Cultures, 12, 2, p. 225-253.

Bavelas, J. B., Chovil, N. D., Lawrie, A. \& A. Wade (1992) Interactive Gestures, Discourse processes, 15 , p. 469-489.

Bavelas, J. B., Chovil, N. D., Coates, L. \& L. Roe (1995) Gestures Specialized for Dialogue, Personality and Social Psychology Bulletin, 21, p. 394-405.

Beattie, N. (1977) Non-verbal aspects of the teaching and learning of foreign languages, AudioVisual Language Journal, 15, p. 175-181.

Bouchard, R. (1998) L'interaction en classe comme polylogue praxéologique [en ligne], Mélanges en hommage à Michel Dabène. Disponible sur : http://www.inrp.fr/rencontres/seminaires/2004/ sem_didac/bouchard_article_1.pdf.

Bouchard, R. (2005) Les interactions pédagogiques comme polylogues [en ligne], Lidil, 31, p. 139-155. Disponible sur : http://lidil.revues.org/150.

Bourdieu, P. (1984/2002) Questions de sociologie, Paris: Les Editions de Minuit. 
Bryman, A. (2012) Social Research Methods, New York: Oxford University Press, Inc.

Calbris, G. (2011) Elements of Meaning in Gesture, Amsterdam: John Benjamins.

Calbris, G. \& J. Montredon (1986) Des gestes et des mots pour le dire, Paris: CLE International.

Cambra Giné, M. (2003) Une approche ethnographique de la classe de langue, Paris: Didier.

Colletta, J.-M. (2005) Communication non verbale et parole multimodale: quelles implications didactiques?, Le français dans le monde-Recherches et Applications, special issue, p. 32-41.

Coquet, F. (2012) Multicanalité de l'expression [en ligne], Entretiens d'Orthophonie, p. 97-114. Disponible sur : http://www.associationcharge.fr/IMG/pdf/orthophonie_97_114_wmk.pdf.

Cosnier, J. (1982) Communications et langages gestuels, in Cosnier, J., Coulon, J., Berrendonner, A. \& C. Kerbrat-Orecchioni (eds) Les voies du langage: communications verbales, gestuelles et animals, Paris: Dunod, p. 255-304.

Dabène, L. (1984) Pour une taxinomie des opérations métacommunicatives en classe de langue étrangère, Études de linguistiques appliquées (ELA), 55, p. 39-46.

De Ruiter, J. P. (2007) Postcards from the Mind. The Relationship Between Speech, Imagistic Gesture, and Thought, Gesture, 7, 1, p. 21-38.

De Saint-Georges, I. (2008) La multimodalité et ses sessources pour l'enseignement-apprentissage, in Filliettaz, L., De Saint-Georges, I. \& B. Duc (eds.) “Vos mains sont intelligentes!": Interactions en formation professionnelle initiale, Université de Genève: Cahiers de la section des sciences de l'éducation, p. 117-158.

Efron, D. (1972) Gesture, Race and Culture, The Hague: Mouton and Co.

Ekman, P. \& W. V. Friesen (1969) Nonverbal Leakage and Clues to Deception, Psychiatry Journal for the Study of Interpersonal Processes, 32, 1, p. 88-106.

Filliettaz, L. (2002) La parole en action. Éléments de pragmatique psycho-sociale, Québec: Editions Nota bene.

Goffman, E. (1956) The Presentation of Self in Everyday Life, Edinburgh: University of Edinburgh.

Goffman, E. (1981) Forms of Talk, Philadelphia, PA: University of Pennsylvania Press.

Goldin-Meadow, S., Nusbaum, H., Kelly, S. D. \& S. Wagner (2001) Explaining Math: Gesturing Lightens the Load, Psychological Science, 12, p. 516-522.

Goodwin, C. (2000) Action and Embodiment within Situated Human Interaction, Journal of Pragmatics, 32, p. 1489-1522.

Gülich, E. \& L. Mondada (2001) Analyse conversationnelle, Methodologie: (Sprache in der Gesellschaft, Sprache und Klassifikation, Datensammlung und-verarbeitung), 1, 2, p. 196-250.

Gullberg, M. (2010) Methodological Reflections on Gesture Analysis in Second Language Acquisition and Bilingualism Research, Second Language Research, 26, 1, p. 75-102.

Hadar, U., Steiner, T. J., Grant, E. C. \& F. Clifford Rose (1984) The Timing of Shifts of Head Postures During Conversation, Human Movement Science, 3, p. 237-245.

Hauge, E. (1999) Some Common Emblems Used by British English Teachers in EFL Classes, in Killick, D. \& M. Parry (eds), Cross-cultural Capability: Promoting the Discipline: Marking Boundaries and Crossing Borders Proceedings, Leeds: Leeds Metropolitan University, p. 405-420.

Johnston, T. (2013) Towards a Comparative Semiotics of Pointing Actions in Signs and Spoken Language, Gesture, 13, 2, p. 109-142. 
Kendon, A. (1988) How Gestures Can Become Like Words, in F. Poyatos (ed) Cross-cultural Perspectives in Nonverbal Communication, Toronto: Hogrefe, p. 131-141.

Kendon, A. (2004) Gesture: Visible Action as Utterance, Cambridge: Cambridge University Press.

Kita, S. \& A. Ozyurek (2003) What Does Cross-Linguistic Variation in Semantic Coordination of Speech and Gesture Reveal? Evidence for an Interface Representation of Spatial Thinking and Speaking, Journal of Memory and Language, 48, p. 16-32.

McGowan, T. (2010) Abstract Deictic Gestures-in-Interaction: A Barometer of Intersubjective Knowledge Development in Small-Group Discussion, Working Papers in Educational Linguistics, 25, 2, p. 55-79.

McNeill, D. (1992) Hand and Mind: What Gestures Reveal About Thought, Chicago: The University of Chicago Press.

McNeill, D. (2005) Gesture and Thought, Chicago: University of Chicago Press.

McNeill, D., Duncan, S. D., Cole, J., Gallagher, S. \& B. Berthenthal (2008) Growth Points from the Very Beginning, Interaction Studies, 9, 1, p. 117-132.

Mondada, L. (2013) Embodied and Spatial Resources for Turn-Taking in Institutional Multi-Party Interactions: Participatory Democracy Debates, Journal of Pragmatics, 46, p. 39-68.

Morris, D. (1997) Le langage des gestes, translated by E. Ochs, Alleur: Nouvelles Éditions Marabout. Muramoto, N. (1999) Gesture in Japanese Language Instruction: The Case of Error Correction, in L. Kathy Heilenman (ed) Research Issues and Language Program Direction, Boston: Heinle and Heinle, p. $143-175$.

Ozyurek, A. (2002) Do Speakers Design Their Cospeech Gestures for Their Addressees? The Effects of Addressee Location on Representational Gestures, Journal of Memory and Language, 46, p. 688704.

Parrill, F. (2008) Form, Meaning, and Convention: A Comparison of a Metaphoric Gesture with an Emblem, in Cienki, A. \& C. Müller (eds) Metaphor and Gesture, Amsterdam/Philadelphia: John Benjamins Publishing Company, p. 195-217.

Payrató, L. \& S. Teßendorf (2014) Pragmatic gestures, in Müller, C., Cienki, A., Fricke, E., Ladewig, S. H., McNeill, D. \& J. Brassem (eds) Body-Language-Communication: An International Handbook on Multimodality in Human Interaction, Volume II, Berlin/Boston: De Gruyter Mouton, p. 1531-1539.

Rivière, V. \& R. Bouchard (2011) Une compétence professionnelle de l'enseignant: gérer la simultanéité des interactions, in Colloque international INRP-ENS "Le travail enseignant au XXI siècle. Perspectives croisées: didactiques et didactique professionnelle”, March 2011, Lyon, France, p. 1-14.

Roth, W.-M. (1999) Discourse and agency in school science laboratories. Discourse Processes, 28,1, p. 27-60.

Santos, F. (2019) Le kappa de Cohen: un outil de mesure de l'accord inter-juges sur des caractères qualitatifs [en ligne], p. 1-10. Disponible sur : http://www.pacea.u-bordeaux.fr/IMG/pdf/ Kappa_Cohen.pdf.

Sloetjes, H. \& P. Wittenburg (2008) Annotation by Category - ELAN and ISO DCR [en ligne], in Calzolari, N., Choukri, K., Maegaard, B., Mariani, J., Odijk, J., Piperidis, S. \& D. Tapias (eds) Proceedings of the 6th International Conference on Language Resources and Evaluation, European Language Resources Association (ELRA), p. 816-820. Disponible sur : http://www.lrec-conf.org/ proceedings/lrec2008/. 
Streeck, J. (2009) Gesturecraft: The Manu-facture of Meaning, Amsterdam/Philadelphia: John Benjamins Publishing Company.

Tabenksy, A. (2014) Gestures, postures, gaze, and other body movements in the $2^{\text {nd }}$ language classroom interaction, in Müller, C., Cienki, A., Fricke, E., Ladewig, S. H., McNeill, D. \& J. Brassem (eds) Body-Language-Communication: An International Handbook on Multimodality in Human Interaction, Volume II, Berlin/Boston: De Gruyter Mouton, p. 1426-1432.

Tellier, M. (2006) L'impact du geste pédagogique sur l'enseignement-apprentissage des langues étrangères: étude sur des enfants de 5 ans, Doctoral dissertation, Université Paris 7- Denis Diderot, $405 \mathrm{p}$.

Tellier, M. (2008) Dire avec des gestes [en ligne], Le français dans le monde, Recherches et Applications : Du discours de l'enseignant aux pratiques de l'apprenant, 44, p. 40-50. Disponible sur : http://fipf.org/sites/fipf.org/files/ra_44_juillet_2008.pdf.

Tellier, M. \& G. Stam (2012) Stratégies verbales et gestuelles dans l'explication lexicale d'un verbe d'action, in V. Rivière (ed) Spécificités et diversités des interactions didactiques, Paris: Riveneuve Editions, p. 357-374.

\section{NOTES}

1. First edited in 1941.

2. McNeill (2005: 6-11) later turned into a complex of separate continua based on four distinct criteria: relationship to speech, relationship to linguistic properties, relationship to conventions, and character of semiosis.

3. All translations from French are ours.

4. Azaoui (2015b: 229-230) supports the idea that pedagogical gestures could be considered in a broader sense. The author posits that it is neither the context (the classroom), nor the professional identity (teachers) that makes these gestures pedagogical, but rather the intention leading to the production of these gestures. Hence, even gestures produced by politicians, doctors, parents, etc. possess a certain degree of didacticity/pedagogicity according to the communicative intention of the speaker.

5. Tellier drew this categorization on Dabène's work (1984) about teachers' roles and claimed that these functions applied to teachers' gestures as well. According to this French linguist, teachers' roles fell into three main distinct but interrelated functions: assessment, classroom management, and information delivery.

6. For example, thumb-up gesture for approval (Tellier, 2008: 44)

7. For example, giving turn to a student with a palm facing up (Tellier, 2008: 44)

8. For example, performing strokes on the belly to illustrate "I like it" in order to convey lexical information (Tellier, 2008: 43)

9. The same gesture is coined as palm up open hand gesture by Müller (2004, as cited in Kendon 2004: 264), palm presentation gesture by Kendon (2004: 265) as a subclass of open hand supine gestures (Kendon, 2004: 264) or simply as presenting gesture by Parrill (2008: 196).

10. According to McNeill (1992: 154) who classifies this gesture within non-conduit metaphoric gestures, it represents nothingness, as if something was running away from the hand(s). The same gesture is called bowling gesture by Morris (1997: 137).

11. The students in any language class often have different linguistic abilities. We can pose that teachers will take into account these differences.

12. The teacher providing the French course is of French nationality. She received her undergraduate degree in teaching of French as a Foreign Language. She also took a master's 
degree in modern literature. As a French teacher, she has 7 years of experience in teaching of French as a Foreign Language. During an informal conversation with the teacher, she affirmed that she performs gestures for facilitating comprehension, regulating the rhythm of the course and evaluating students. Her statement is in parallel with Tellier's $(2006,2008)$ functional categorization.

13. The instructor, aged about 40 at the time of the video-recording in 2011, has qualified in French as an L1 teacher, but she had been teaching French as an L2 part-time to newly arrived migrants for 4 years. She had attended teacher training to work with NAMs.

14. The video recordings of both contexts were originally made within the scope of our doctoral dissertations.

15. According to the proficiency scale described in the Common European Framework of Reference for Languages: http://www.coe.int/t/dg4/linguistic/cadre1_en.asp

16. Only the second tier "Conv_Gest_1" ("Topic 1" and "Interactive 1" constituting the coding alternatives) was counter-coded for practical reasons.

17. In this example, we also notice that interactive subfunctions may overlap because when the teacher asks the student a question via the deictic gesture, she also gives him the turn. Yet, the main subfunction is seeking a particular response/answer in our point of view.

18. Some conventionalized teaching gestures -referred to as teaching emblems in this paper- may be used regularly in instructional contexts and they do not require verbal clues to be interpreted correctly by the students. Various authors (Hauge, 1999; Muramoto, 1999; Azaoui, 2013) have mentioned these gestures in their work. Their major difference with cultural emblems is that they may not be used spontaneously out of the class (for example, the repeat emblem or the cupped hand behind the ear), and that pedagogical emblems serve teaching functions. Furthermore, some of them are specific to classroom interactions (for further details, see Azaoui, 2013).

19. Not in the sense of citing a previous point but of illustrating the act of coming back to that point.

\section{RÉSUMÉS}

Depuis les travaux de Goffman (1956), il est admis que les interactions sociales sont intrinsèquement multimodales, c'est-à-dire qu'elles impliquent, outre la production verbale, divers paramètres non verbaux tels que les gestes, la proxémique, la posture, l'expression du visage, etc. Les recherches portant plus spécifiquement sur les gestes ont montré l'importance de cette action visible (Kendon, 2004), et divers travaux ont permis de comprendre sa relation avec la parole et son rôle dans l'interaction. Les réflexions sur la classification de ces gestes ont abouti à plusieurs propositions que l'on peut ramener à trois dimensions principales: émotionnelle, référentielle et discursive.

Bavelas et ses collaborateurs $(1992,1995)$ ont proposé de prendre en compte une catégorie de gestes interactifs, que les auteures définissent comme ceux dont la fonction est de favoriser le maintien de la conversation en tant que système social et d'aider les interlocuteurs à coordonner leur dialogue. L'argument motivant leur telle taxonomie était que les recherches antérieures sur les gestes étaient basées sur des données provenant de contextes monologaux. Or, ils ont observé que les contextes les plus courants pour la production de discours étaient les dialogues en face à face, ce qui introduit la nécessité pour les interlocuteurs de coordonner leur dialogue ou de se 
référer au destinataire. Bien que l'argument initial de Bavelas et al. $(1992,1995)$ soit cohérent avec une approche sociale de la conversation, nous pensons qu'une définition plus large de l'interaction peut également être envisagée et que les gestes interactifs peuvent englober des contextes comportant plus de deux participants. Les contextes d'enseignement en constituent un exemple. On peut admettre que les salles de classe, parce que socialement organisés, se définissent, entre autres, par leurs dimensions polylogales et polyfocales, qui facilitent les interactions simultanées et rendent plus complexe la gestion multimodale de l'interaction par les enseignants.

Toute taxonomie étant amenée à être interrogée à l'aune de nouveaux contextes et situations possédant leur propres spécificités (Kendon, 2004; Bourdieu, 1984), nous pensons que celles de la classe de langue invitent à réviser la catégorisation des gestes interactifs proposée par Bavelas et al. (1995).

Cadre méthodologique

Le groupe d'étude est composé de deux professeurs de français enseignant le français dans les écoles secondaires en Turquie et en France dans deux contextes pédagogiques différents : il s'agit respectivement $d u$ français langue étrangère enseigné aux étudiants turcs de français en Turquie, et du français langue seconde enseigné aux migrants nouvellement arrivés qui avaient été scolarisés en France pendant au plus un an au moment des enregistrements vidéo. Le niveau de compétence linguistique des étudiants en Turquie et en France était respectivement de A1 et A1-A2. Les données ont été recueillies de manière empirique par le biais des enregistrements vidéo de deux sessions de français (d'une durée de 45 minutes pour chaque contexte d'enseignement).

Résultats

Nos analyses nous conduisent à proposer diverses adaptations des conclusions de Bavelas et al. $(1992,1995)$ au contexte spécifique que constituent les interactions didactiques.

Pour un élargissement de certaines sous-fonctions

Si l'on revient dans un premier temps aux sous-fonctions des gestes interactifs mises à jour par les auteurs, notre analyse nous conduit à en réviser certaines. Nous avançons l'idée que la sousfonction de recherche peut également comprendre l'acte de susciter une réponse particulière de la part des étudiants. En outre, les gestes de présentation ne concernent pas seulement la présentation d'une idée, mais ils peuvent également inclure le geste en négatif, à savoir celui qui symbolise un retrait ou un rejet. Par ailleurs, la coordination des tours implique, pour nous, à la fois les gestes relatifs aux tours de parole et ceux qui régissent certaines activités de jeu de rôle ou certaines tâches à réaliser au tableau noir/blanc.

Vers un continuum gestes informationnels-gestes interactifs

Si l'on aborde à present la définition générale des gestes interactifs soumise par les auteurs, et notamment la distinction qu'ils proposent entre gestes informationnels et interactifs, les résultats de notre analyse qualitative montrent, si l'on s'appuie sur la notion de polysigne de Calbris (2011 : 163), que l'auteure définit comme un geste qui exprime plusieurs notions simultanément à une occasion d'utilisation, que certains gestes déictiques ou métaphoriques accompagnant les questions dans les exemples analysés dans nos corpus nous conduiraient à envisager un continuum permettant de réfléchir en termes de degré de référentialité/ interactivité, plutôt qu'en termes de topique ou de gestes interactifs.

Les emblèmes, des gestes interactifs

Bavelas et ses collaborateurs $(1992,1995)$ présentent les gestes emblématiques comme une catégorie distincte des gestes conversationnels. Cependant, nous estimons que les emblèmes constituent une catégorie de gestes dimensionnels et non fonctionnels. Ils ne sont pas toujours produits pour clarifier le sens du mot; ils constituent plutôt, parfois, un mouvement presque automatique destiné à créer une réaction particulière du côté du destinataire. Ainsi, et bien que redondant à la parole, l'emblème intensifie le mot et possède une valeur illocutoire (pour le 
locuteur)/perlocutoire (pour l'interlocuteur). Il est donc, de notre point de vue, parfois interactif. Cette idée est d'ailleurs soutenue par Kendon (2004 : 339), lorsqu'il affirme que les emblèmes (quotable gestures) peuvent être utilisés pour le contrôle interpersonnel.

Citer des supports sémiotiques ou des interventions d'élèves, une sous-fonction du geste interactif

Différents outils sémiotiques à disposition des enseignants dans la classe peuvent, pour différentes raisons parfois purement pratiques (gagner du temps et passer à l'activité suivante), servir de supports pédagogiques à divers degrés. Nos observations montrent que les enseignants ne citent pas seulement les contributions verbales des élèves mais aussi d'autres matériels sémiotiques/pédagogiques. Dans ce cas, le geste produit n'a pas pour fonction principale d'apporter une information qui permettrait de clarifier la réponse précédente d'un élève. Sur le plan discursif, le geste renvoie alors à un élément déjà partagé par les participants dans le cadre de l'interaction en classe. Aussi, à moins que le geste ne concerne un point nouvellement soulevé ou produit à des fins de clarification, nous considérons ces gestes de rappel comme ayant un caractère interactif.

Cadre méthodologique

Le groupe d'étude est composé de deux professeurs de français enseignant le français dans les écoles secondaires en Turquie et en France dans deux contextes pédagogiques différents : il s'agit respectivement $d u$ français langue étrangère enseigné aux étudiants turcs de français en Turquie, et du français langue seconde enseigné aux migrants nouvellement arrivés qui avaient été scolarisés en France pendant au plus un an au moment des enregistrements vidéo. Le niveau de compétence linguistique des étudiants en Turquie et en France était respectivement de A1 et A1-A2. Les données ont été recueillies de manière empirique par le biais des enregistrements vidéo de deux sessions de français (d'une durée de 45 minutes pour chaque contexte d'enseignement).

Résultats

Nos analyses nous conduisent à proposer diverses adaptations des conclusions de Bavelas et al. $(1992,1995)$ au contexte spécifique que constituent les interactions didactiques.

Pour un élargissement de certaines sous-fonctions

Si l'on revient dans un premier temps aux sous-fonctions des gestes interactifs mises à jour par les auteurs, notre analyse nous conduit à en réviser certaines. Nous avançons l'idée que la sousfonction de recherche peut également comprendre l'acte de susciter une réponse particulière de la part des étudiants. En outre, les gestes de présentation ne concernent pas seulement la présentation d'une idée, mais ils peuvent également inclure le geste en négatif, à savoir celui qui symbolise un retrait ou un rejet. Par ailleurs, la coordination des tours implique, pour nous, à la fois les gestes relatifs aux tours de parole et ceux qui régissent certaines activités de jeu de rôle ou certaines tâches à réaliser au tableau noir/blanc.

Vers un continuum gestes informationnels-gestes interactifs

Si l'on aborde à present la définition générale des gestes interactifs soumise par les auteurs, et notamment la distinction qu'ils proposent entre gestes informationnels et interactifs, les résultats de notre analyse qualitative montrent, si l'on s'appuie sur la notion de polysigne de Calbris (2011 : 163), que l'auteure définit comme un geste qui exprime plusieurs notions simultanément à une occasion d'utilisation, que certains gestes déictiques ou métaphoriques accompagnant les questions dans les exemples analysés dans nos corpus nous conduiraient à envisager un continuum permettant de réfléchir en termes de degré de référentialité/ interactivité, plutôt qu'en termes de topique ou de gestes interactifs.

Les emblèmes, des gestes interactifs

Bavelas et ses collaborateurs $(1992,1995)$ présentent les gestes emblématiques comme une catégorie distincte des gestes conversationnels. Cependant, nous estimons que les emblèmes constituent une catégorie de gestes dimensionnels et non fonctionnels. Ils ne sont pas toujours

TIPA. Travaux interdisciplinaires sur la parole et le langage, 36 | 2020 
produits pour clarifier le sens du mot; ils constituent plutôt, parfois, un mouvement presque automatique destiné à créer une réaction particulière du côté du destinataire. Ainsi, et bien que redondant à la parole, l'emblème intensifie le mot et possède une valeur illocutoire (pour le locuteur)/perlocutoire (pour l'interlocuteur). Il est donc, de notre point de vue, parfois interactif. Cette idée est d'ailleurs soutenue par Kendon (2004 : 339), lorsqu'il affirme que les emblèmes (quotable gestures) peuvent être utilisés pour le contrôle interpersonnel.

Citer des supports sémiotiques ou des interventions d'élèves, une sous-fonction du geste interactif

Différents outils sémiotiques à disposition des enseignants dans la classe peuvent, pour différentes raisons parfois purement pratiques (gagner du temps et passer à l'activité suivante), servir de supports pédagogiques à divers degrés. Nos observations montrent que les enseignants ne citent pas seulement les contributions verbales des élèves mais aussi d'autres matériels sémiotiques/pédagogiques. Dans ce cas, le geste produit n'a pas pour fonction principale d'apporter une information qui permettrait de clarifier la réponse précédente d'un élève. Sur le plan discursif, le geste renvoie alors à un élément déjà partagé par les participants dans le cadre de l'interaction en classe. Aussi, à moins que le geste ne concerne un point nouvellement soulevé ou produit à des fins de clarification, nous considérons ces gestes de rappel comme ayant un caractère interactif.

This paper discusses the concept of interactive gestures in instructional contexts whose interactional specificity lends itself to the study of these gestures which typically contribute to the process of meaning-making and interpersonal relationship. Our empirically grounded account is based upon the analysis of video recorded classroom interactions of French as a foreign language in Turkey and French as a second language in France. The results show that the majority of the teaching gestures had interactive functions and that a degree of topicality/ interactivity may be considered for some gestures; therefore, a clear categorical distinction may not be possible in some situations. Furthermore, the specificity of classroom interactions leads us to consider some gestures that are not directed towards the addressee as also interactive.

\section{INDEX}

Keywords : interactive gestures, teaching gestures, classroom interactions, polyfocality

Mots-clés : gestes interactifs, gestes pédagogiques, interactions didactiques, polyfocalité

\section{AUTEURS}

\section{CAN DENIZCI}

Istanbul University-Cerrahpasa, H.A.Y. Faculty of Education, Department of French Language Teaching

can.denizci@istanbul.edu.tr

\section{BRAHIM AZAOUI}

LIRDEF, Univ Montpellier, Univ Paul Valery Montpellier 3, Montpellier, France

brahim.azaoui@umontpellier.fr 